
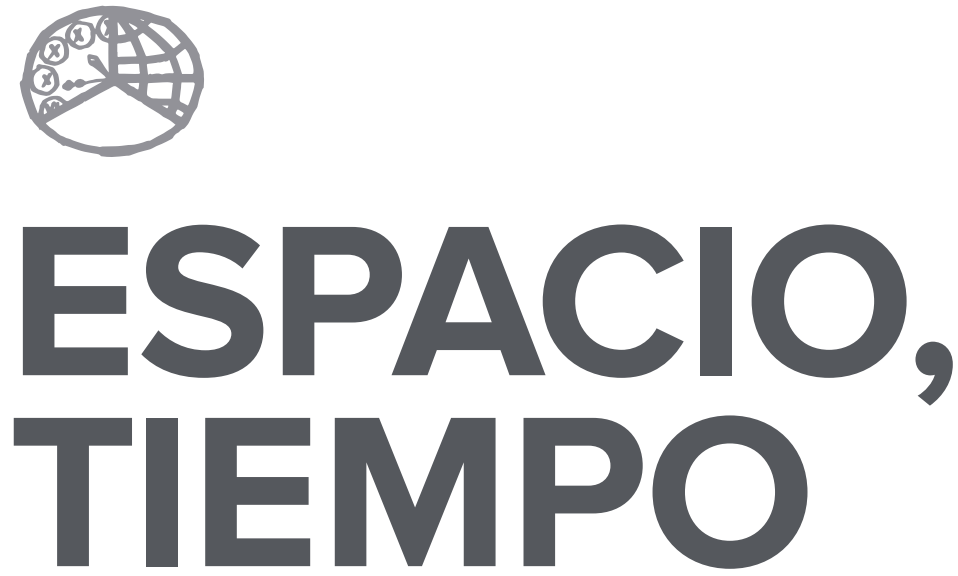

AÑO 2016

ISSN 0214-9745

E-ISSN 2340-1362
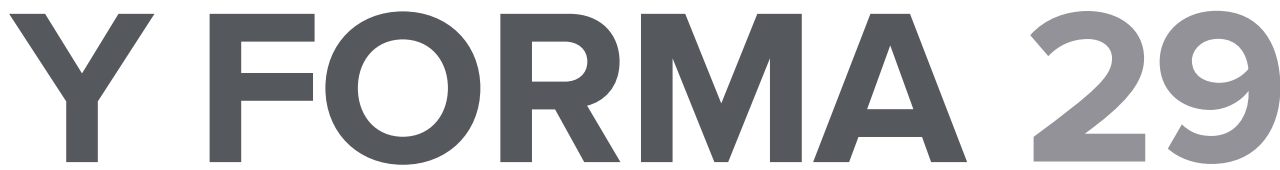

SERIE III HISTORIA MEDIEVAL

REVISTA DE LA FACULTAD DE GEOGRAFÍA E HISTORIA 


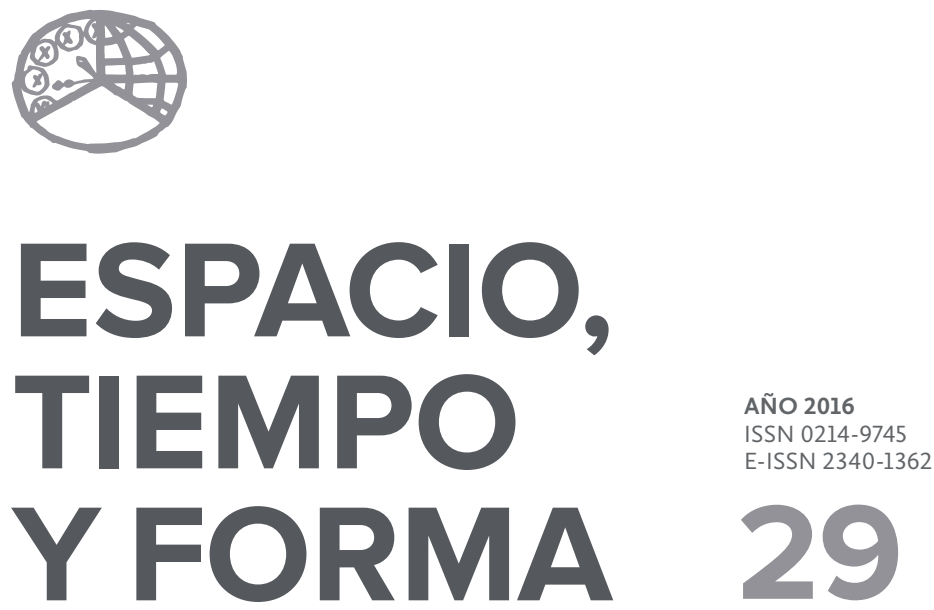

SERIE III HISTORIA MEDIEVAL

REVISTA DE LA FACULTAD DE GEOGRAFÍA E HISTORIA

http://dx.doi.org/10.5944/etfiii.29.2016

\section{UกED}

UNIVERSIDAD NACIONAL DE EDUCACIÓN A DISTANCIA 
La revista Espacio, Tiempo y Forma (siglas recomendadas: ETF),

de la Facultad de Geografía e Historia de la UNED, que inició su publicación el año 1988, está organizada de la siguiente forma:

$$
\begin{aligned}
& \text { SERIE I - Prehistoria y Arqueología } \\
& \text { SERIE II - Historia Antigua } \\
& \text { SERIE III - Historia Medieval } \\
& \text { SERIE IV - Historia Moderna } \\
& \text { SERIE V - Historia Contemporánea } \\
& \text { SERIE VI - Geografía } \\
& \text { SERIE VII - Historia del Arte }
\end{aligned}
$$

Excepcionalmente, algunos volúmenes del año 1988 atienden a la siguiente numeración:
N. ${ }^{\circ} 1$ - Historia Contemporánea
N. ${ }^{\circ} 2-$ Historia del Arte
N. ${ }^{\circ} 3-$ Geografía
N. ${ }^{\circ} 4 \quad-$ Historia Moderna

ETF no se solidariza necesariamente con las opiniones expresadas por los autores.

UNIVERSIDAD NACIONAL DE EDUCACIÓN A DISTANCIA

Madrid, 2016

SERIE III - HISTORIA MEDIEVAL N. ${ }^{\circ} 29,2016$

ISSN 0214-9745 · E-ISSN 2340-1362

DEPÓSITO LEGAL M-21037-1988

URL: ETF III - HISTORIA MEDIEVAL · http://revistas.uned.es/index.php/ETFIII

DISEÑO Y COMPOSICIÓN

Carmen Chincoa Gallardo · http://www.laurisilva.net/cch

Impreso en España · Printed in Spain 


\section{ARTÍCULOS}





\title{
EL TUMBO DE SAN PEDRO DE \\ MONTES COMO INSTRUMENTO \\ DE RECREACIÓN DE LA \\ MEMORIA INSTITUCIONAL
}

\section{THE CARTULARY OF SAN PEDRO DE MONTES AS A TOOL FOR RECONSTRUCTING INSTITUTIONAL MEMORY}

\author{
Leticia Agúndez San Miguel ${ }^{1}$ \\ Recepción: 2015/9/19 . Comunicación de observaciones de evaluadores: 2015/11/29 . \\ Aceptación: 2016/3/11 \\ DOI: http://dx.doi.org/10.5944/etfiii.29.2016.15297
}

\section{Resumen ${ }^{2}$}

Este artículo pretende indagar en las lógicas de producción del cartulario conocido como Tumbo de San Pedro de Montes para valorar su aportación como instrumento de recreación de la memoria institucional de este monasterio leonés. El análisis de las diferentes estrategias de selección y clasificación que guiaron la arquitectura de este códice diplomático constituye el método principal para la consecución de este propósito. Así, la identificación de los diferentes parámetros memoriales que articulan el discurso historiográfico propuesto en sus folios nos advierte de la existencia de diferentes etapas de recreación de la memoria monástica, de sus tiempos de referencia y de su utilidad variable para los propósitos proyectados con la confección de este cartulario. Un resultado que evidencia la necesaria atención de los investigadores a la materialidad del cartulario para el adecuado aprovechamiento de su contenido.

\section{Palabras clave}

San Pedro de Montes; cartulario; memoria institucional.

1. Universidad del País Vasco. C.e.: let.agundez@gmail.com

2. Este trabajo se ha desarrollado con el apoyo de una ayuda para la Especialización de Personal Investigador del Vicerrectorado de Investigación de la UPV/EHU, Universidad del País Vasco, (2013) y dentro del proyecto dirigido por Juan José Larrea y Francesca Tinti: Escribir el espacio en la Alta Edad Media, financiado por el Ministerio de Economía y Competitividad, HAR2013-44576-P. 


\begin{abstract}
This article aims to explore the logic of production of the cartulary known as the Tumbo of San Pedro de Montes in order to assess its contribution as an instrument for the reconstruction of the institutional memory of this monastery in the kingdom of Leon. The methodology used for this task consists of an analysis of the strategies of selection and classification that established the structure of this diplomatic codex. This will allow us to identify the different memory parameters that construct the historiographical discourse present within it. Hence, we can gauge the existence of various stages in the reconstruction of the monastery's memory, of its time frame and of the various uses of the cartulary's projected purpose. This study confirms the importance of the material dimension of this cartulary for the adequate use of its content by researchers.
\end{abstract}

\title{
Keywords
}

San Pedro de Montes; Cartulary; Institutional Memory. 


\section{INTRODUCCIÓN}

El monasterio de San Pedro de Montes ha sido objeto de un merecido reconocimiento historiográfico, pese a la escasez de fuentes que se conservan del mismo. Su prestigiosa vinculación con destacados hombres santos en su época fundacional y su preeminencia dentro de la denominada Tebaida berciana justifican su interés para los especialistas de la Edad Media ${ }^{3}$. El recurso al cartulario conocido como Tumbo Viejo de San Pedro de Montes, aunque originariamente titulado Tumbo Antiguo, ha supuesto el único testimonio documental que han aprovechado los investigadores para tratar de reconstruir, en lo posible, la historia de este cenobio. Por su parte, el valor de los cartularios como fuentes de recreación de la memoria institucional de la casa comanditaria, entre otras atribuciones, ha sido ampliamente validado en los últimos años mediante estudios tanto internacionales como nacionales ${ }^{4}$.

En esta misma línea de interés se inscribe este artículo que pretende avanzar en el conocimiento de la memoria institucional conservada de este famoso monasterio leonés mediante el análisis de las lógicas de producción que determinaron el contenido del tumbo y que, por tanto, condicionaron su significado como proyecto historiográfico. Con ello se aspira, dentro de las limitaciones relativas a la transmisión de la documentación disponible, identificar y justificar el momento de creación y/o recuperación de los diferentes parámetros memoriales que articularon el discurso propuesto en este cartulario. El análisis de las diferentes

3. En efecto, la fundación de este monasterio por san Fructuoso en la primera mitad del siglo VII, su ampliación por san Valerio en esa misma centuria y su restauración por san Genadio en el siglo IX constituyeron una enorme fuente de prestigio espiritual para este centro. Según el padre Henrique Flórez este monasterio era uno de los miembros más destacados de lo que denominó la «Tebaida berciana», FlóreZ, Henrique, España Sagrada, Tomo XV, Madrid, 1759 , p. 26.

4. Sin ánimo de exhaustividad: GEARY, Patrick, «Entre gestion et gesta», en GUYOTJEANNIN, Olivier, MORELLE, Laurent y PARISSE, Michel (coords.): Les Cartulaires. Actes de la Table ronde organisée par I'Ecole nationale de chartes et le G.D.R. 121 du C.N.R.S. (Paris, 5-7 décembre 1991). Paris, École de Chartes, 1993, pp. 13-25; SANZ FuENTES, María Josefa, «Cartularios: historia y falsificación histórica», en GARCíA DE CORTÁZAR, José Ángel (coord.): La memoria histórica de Cantabria, Santander, Universidad de Cantabria, 1996, pp. 147-154; KosTO, Adam, «The Liber feudorum maior of the counts of Barcelona: the cartulary as an expression of power», Journal of Medieval History, vol. 27/1 (2001), pp. 1-22; ChASTANG, Pierre, Lire, écrire, transcrire: Le travail des rédacteurs de cartulaires en Bas-Languedoc (Xle-XIIle siècles), Paris, CTHS, 2002 ; BOUCHARD, Constance, «Monastic cartularies: organizing eternity», en KosTO, Adam y Winroth, Anders (eds.) : Charters, cartularies and archives: the preservation and transmission of documents in the medieval west. Toronto, Pontifical Institute of Mediaeval Studies, 2002, pp. 22-32; TINTI, Francesca, «Si litterali memorie commendaretur: memory and cartularies in eleventh-century Worcester», en BAXTER, Simon (ed.): Early Medieval Studies in Memory of Patrick Wormald, Farnham, Asghate, 2009, pp. 475-97; Peterson, David, «Reescribiendo el pasado. El «Becerro Galicano» como reconstrucción de la historia institucional de San Millán de la Cogolla», Hispania, 69 (2009), pp. 653-682; RoDRíGUEZ, Elena E. y CARCíA, Antonio C. (coords.): La escritura de la memoria: los cartularios, Huelva, Universidad de Huelva, 2011; Calleja Puerta, Miguel, «Cartularios y construcción de la memoria monástica en los reinos de León y Castilla durante el siglo XII», en LAMAZOU-DUPLAN, Veronique y RAMIREZ VAQUERO, Eloísa (dirs.): Les cartulaires médiévaux. Écrire et conserver la mémoire du pouvoir, le pouvoir de la mémoire, Pau, Puppa, 2013, pp. 187-197; Escalona, Julio y SIRANTOINE, Hélene (dirs.) : Chartes et cartulaires comme instruments de pouvoir. Espagne et Occident chrétien (VIIle-XIle siècles), Tolouse, 2014; TOMÁs FACI, Guillermo, «La construcción de la memoria escrita en los archivos eclesiásticos de Ribagorza (ss. XI-XIII)», Edad Media. Revista de Historia, 16 (2015), pp. 89-105; Agúndez SAN MıgueL, Leticia, «Estudio de las transformaciones formales y funcionales en el género de los cartularios: el ejemplo de los becerros del monasterio de Sahagún (siglos XI-XIV)», Journal of Medieval Iberian Studies, 7:1, 2015, pp. 44-56; BouCHARD, Constance, Rewriting saints and ancestors. Memory and Forgetting in France, 500-1200, Philadelphia, Penn, 2015, pp. 9-37. 
estrategias de selección y clasificación que guiaron la arquitectura de este códice diplomático constituye el método principal para la consecución de este propósito.

\section{TUMBO DE SAN PEDRO DE MONTES: ESTADO DE LA CUESTIÓN}

La importancia del Tumbo Antiguo de San Pedro de Montes 5 se ha apreciado tempranamente por los investigadores debido a su valor como corpus transmisor de más de cuatrocientos noventa documentos. En efecto, de todos los diplomas incluidos en este códice, referentes a los siglos IX al XV, tan sólo tres han llegado hasta la actualidad en su versión de copia posterior ${ }^{6}$. Este dato permite valorar la relevancia de este cartulario como testimonio documental de excepción para el conocimiento de este monasterio berciano ${ }^{7}$. Sin embargo, desde las premisas expuestas por la Historia Social de la Cultura Escrita, su aportación transciende su mera función de custodio documental para incidir en su dimensión material y en las intencionalidades vinculadas a su proceso de producción como medio para comprender esta fuente dentro de su propia historicidad ${ }^{8}$. Así, el estudio del cartulario adquiere sentido, entre otras funciones, dentro de su contribución al proceso de consolidación memorial de la institución comanditaria derivado de las estrategias de selección y clasificación documental que articularon tanto su primigenia redacción como las múltiples incorporaciones que determinaron su actual estado ${ }^{9}$. Consecuentemente, la justificación de la elección de este códice diplomático para un estudio de este tipo reside no sólo en su excepcional valor

5. Desde ahora TSPM.

6. Quintana Prieto, Augusto, Tumbo Viejo de San Pedro de Montes, León, Centro de Estudios e Investigación san Isidoro, 1971, p. 21 (= TVSP). En el Archivo Histórico Nacional se conservan cuatro legajos y cinco libros de los siglos XVI al XIX que contienen los registros de aperos y fueros del cenobio. Clero Secular-Regular, 2639/2642-5217/5221.

7. El monasterio leonés de San Pedro de Montes, actualmente en ruinas, se halla en la población de Montes de Valdueza, a menos de 20 kilómetros de Ponferrada en dirección sur.

8. Como señala Pierre Chastang, desde una aproximación crítica a los documentos, «la materialidad del texto no debe ser simplemente una oportunidad para un trabajo de crítica tradicional o para situar el texto dentro de una tradición manuscrita sino, más bien, para considerar esa materialidad como el testimonio de la historicidad del texto, de su implicación dentro de los procesos sociales y culturales que el historiador debe descifrar». CHASTANG, Pierre, «Culture médiévale de l'écrit et cartulaires», en MUNITA LoINAZ, José Antonio (coord.): Mitificadores del pasado, falsarios de la Historia. Historia, Bilbao, Universidad País Vasco, 2012, p. 72.

9. Según Pierre Chastang en alusión a las novedades respecto a la evolución de la cultura escrita manifiestas en el siglo XIII, «En el mundo monástico de los siglos XI y XII el escrito asume progresivamente nuevas funciones memoriales necesarias para la conservación de las formas de transacción material y simbólica (...). La protección del señorío monástico, a la cual el escrito contribuye ampliamente, no se reduce simplemente a una cuestión jurídica. (...) El escrito reviste una dimensión pragmática creciente- defender el dominio monástico terrenal- al tiempo que contribuye a fijar la memoria y la identidad de las instituciones y de las comunidades, tanto si se trata de establecimientos monásticos o de grupos aristocráticos». CHASTANG, Pierre, «Écrire, remployer, archiver. Quelques remarques sur l'évolution de la culture de I'écrit au Moyen Âge central», en VV. AA.: La cultura en la Europa del siglo XIII. Emisión, intermediación, audiencia, Pamplona, Gobierno de Navarra, 2014, p. 137. Por su parte, Miguel Calleja apunta, «El cartulario se convirtió en una práctica asentada en la que convivían las distintas funciones que normalmente se le atribuyen, y en particular la creación de memorias prestigiosas que, al plasmar y difundir una imagen de realidad, se convertían en agentes de estructuración de la sociedad en torno a unos valores y unas memorias determinados». Respecto a las principales 
como garante documental de la historia del monasterio de San Pedro de Montes sino también en su inexplotada proyección como instrumento (re)creador de la memoria de este cenobio en sus diferentes etapas de confección.

El TSPM ha sido protagonista de muy poco estudios propios hasta la actualidad con excepción de su edición por Augusto Quintana ${ }^{\mathrm{IO}}$ y del estudio morfosintáctico y transcripción que Celestino Domínguez le dedicó ${ }^{\text {II }}$. Sin embargo, la exclusividad de la documentación conservada en sus folios le ha convertido en objeto de un amplio interés para los investigadores de la Edad Media. Ciertamente, a principios del siglo XIX el abad del cenobio Joaquín Herrezuelo hizo uso de este cartulario para recrear las memorias del monasterio ${ }^{\mathrm{I2}}$. Más recientemente, algunos estudiosos han rastreado en sus folios para avanzar en el conocimiento sobre la historia de este cenobio. Entre estos investigadores cabe subrayar el trabajo de Mercedes Durany Castrillo quien, además de consagrar su tesis de licenciatura al estudio del dominio señorial de este monasterio benedictino entre los siglos $\mathrm{XI}$ al XIII, ha realizado algunas de las contribuciones más valiosas que se pueden encontrar sobre esta institución ${ }^{13}$. Otra investigadora que, de forma individual o conjuntamente con Mercedes Durany, ha destacado en el interés por este cenobio es María del Carmen Rodríguez cuya tesis de licenciatura analizó la estructura

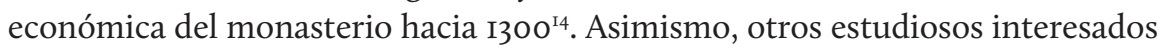
en el TSPM han explotado, generalmente con menor intensidad, su riqueza tanto

funciones reconocidas en estos códices diplomáticos este autor señala: «gestión, protección y conmemoración». Calleja Puerta, Miguel, op. cit., p. 195 y p. 192.

10. Su edición fue realizada por Augusto Quintana Prieto quien asumió esta labor como un trabajo de edición cronológico de los diplomas conservados en sus folios lo que originó una doble numeración: la asignada a los documentos dentro del propio tumbo y la atribuida por el editor a los mismos. Esta metodología beneficia el análisis individual de los documentos aunque al descontextualizar su orden dentro del códice contribuye a lo que Geary denomina la invisibilidad del cartulario. GEARY, Patrick, op. cit., p.13-15. Sobre la problemática reciente en la edición de fuentes diplomáticas véase TINTI, Francesca, «Fuentes escritas: transcripción, digitilización, historia social de la cultura escrita», en LóPEZ OJEDA, Esther (coord.): Nuevos temas, nuevas perspectivas en historia medieval, Logroño, Instituto de Estudios Riojanos, 2015, pp. 59-82. Por otra parte, pese al meritorio trabajo de Quintana, su edición presenta algunos errores en la numeración de los folios, entre otras cuestiones. Así, por ejemplo, el texto con el número 363 según la edición y con el 17 según el tumbo no se encuentra entre los folios séptimo y noveno sino entre el sexto y el octavo. Además, son escasas las ocasiones en las que Quintana precisa si el documento editado se encuentra en el recto o verso del folio, produciéndose errores incluso en estas limitadas precisiones. Igualmente, existen ciertas equivocaciones respecto a elementos decorativos. Por ejemplo, cuando en la descripción del tumbo el editor señala que existe una sola figura humana dibujada en el margen inferior del f. zov es necesario apuntar que existe otro dibujo de dos figuras femeninas y trazo similar, aunque más borroso, en el f. 21r. Estas decoraciones inauguran y cierran, respectivamente, el cuarto cuaderno del tumbo a modo de reclamo. Finalmente, algunas de las afirmaciones que este editor realiza respecto a la materialidad del códice o al trabajo de los copistas que participaron en el mismo son cuestionadas a lo largo de este estudio. TVSP, pp.9-33.

11. Domínguez, Celestino, Cartulario latino de San Pedro de Montes: transcripción del texto, comentario morfosintático, léxico. Tesis doctoral, León, Universidad de León, 1991.

12. Herrezuelo, Joaquín, Historia de San Pedro de Montes. Se conserva una copia de este manuscrito en el Archivo Diocesano de Astorga.

13. Durany, Mercedes, San Pedro de Montes. El dominio de un monasterio benedictino de El Bierzo (siglos XI-XIII), Institución Fray Bernardino, León, 1976; «San Pedro de Montes en la Edad Media», en Álvarez PalenzUela (coord.): Actas de San Pedro de Montes. Luz en la memoria, Ponferrada, Instituto de Estudios Bercianos, 2006, pp. 27-77.

14. Rodríguez González, María del Carmen, Estructura económica del dominio del monasterio de San Pedro de Montes hacia 1300. Tesis de Licenciatura, Universidad de Santiago de Compostela, 1975; junto con Mercedes Durany: «El señorío de un monasterio berciano. San Pedro de Montes en el valle de Valdueza (900-1300)», en VV. AA.: Semana de Historia del monaquismo Cántabro-Astur-Leonés, Oviedo, 1982, pp. 335-359; «El sistema antroponímico en El Bierzo: 
desde el punto de vista histórico como filológico o, incluso, con la finalidad de reconstruir el primitivo conjunto monástico ${ }^{15}$.

\section{TUMBO DE SAN PEDRO DE MONTES: DESCRIPCIÓN Y CONTEXTUALIZACIÓN}

En este apartado se pretende exponer brevemente las principales características que definen las lógicas formales de este cartulario para valorar cómo éstas determinan el discurso memorial contenido en sus folios. El TSPM es un voluminoso códice de pergamino conservado en el Archivo Histórico Diocesano de Astorga con la signatura R.I. La encuadernación actual que presenta, realizada con piel sobre pastas de tabla, no es la original sino que sea, probablemente, del siglo XIX o. incluso, de principios del siglo pasado. La organización de este códice, cuyas medidas son 33 centímetros de alto y 22 de ancho, comienza con tres hojas de guarda, continúa con nueve folios sin numerar que contienen el título ${ }^{\mathrm{I} 6}$, el índice ${ }^{\mathrm{I7}}$ y el documento de confirmación del coto monástico por Sancho $\mathrm{IV}^{\mathrm{I} 8}$, sigue con cincuenta y tres folios numerados y termina con otras tres hojas de guarda ${ }^{19}$. Su

tumbo de San Pedro de Montes. Siglos IX al XIII», en Martínez Sopena, Pascual (coord.): Antroponimia y sociedad, Santiago de Compostela, 1995, pp. 73-102.

15. Algunas de las aportaciones más destacadas son: QuinTANA, Augusto, «El privilegio de Ordoño Il a San Pedro de Montes», Archivos Leoneses, 21 (1957), pp. 77-134; Luengo, José María, «De la Tebaida leonesa: Montes y Penalba», Revista Tierras de León, 22 (1962), pp. 25-41; PENSADO TORNÉ, José Luis, «El léxico Hispánico Occidental en el «Tumbo Viejo» de San Pedro de Montes», Anuario galego de filoloxia, 10 (1983), pp. 43-78; PUENTE, Ricardo, Los monasterios de Santiago de Peñalba y de San Pedro de Montes, León, 1992; Martínez Tejera, Artemio Manuel, «San Pedro de Montes y la ermita de la Santa Cruz», Historia 16, 227 (1995), pp. 112-117; Pérez GonzÁlez, Maurilio, «Galleguismo y/o leonesismos en el Tumbo de San Pedro de Montes», Contextos, $25-26$ (1995), pp. 135-150; Álvarez VILLAR, Julián, «Breve Historia de San Pedro de Montes», Estudios Bercianos, 26 (2001), pp. 105-111; MArtínez Tejera, Artemio Manuel, «Cenobios leoneses altomedievales ante la europeización: San Pedro y San Pablo de Montes, Santiago y San Martín de Peñalba y San Miguel de Escalada», Hispania Sacra, 109 (2002), pp.87-108; MARTínez Fuertes, Benjamín, Montes y Peñalba: ensayo históricoartístico, La Carruna, ed. A. Álvarez, 2004; Alonso Álvarez, Pedro, Historia del monasterio de San Pedro de Montes (646-2003), Arganza, Ed. Pedro Álvarez, 2006; TESTón TURIEL, Juan Antonio, El monacato en la diócesis de Astorga en los periodos antiguo y medieval: la tebaida berciana, León, Universidad de León, 2008, pp. 315-330; GonZÁLEz RODRíGUEZ, Rafael, «Los relieves altomedievales de la ermita de la Santa Cruz de Montes de Valdueza», Estudios Bercianos, 32-33 (2008), pp. 53-78; MARTín VIso, Iñaki, «Monasterios y redes sociales en el Bierzo altomedieval», Hispania, 237 (2011), pp. 9-38; Zaragoza I PAscual, Ernesto, «Abadologio de san Pedro de Montes (siglos VII-XIX)», Compostellanum, 57 (2012), pp. 277-312; MARTín VISO, Iñaki, «La memoria de los «hombres santos» en el monacato hispano: el caso de la región del Bierzo», Imago temporis. Medieum Aevum, n 6 (2012), pp. 440-461. Dos volúmenes colectivos se han dedicado al estudio de este cenobio: Revista Bierzo: San Pedro de Montes, Editorial Basílica de la Encina, 1997; Álvarez Palenzuela (coord.), Actas de San Pedro de Montes. Luz en la memoria, Ponferrada, Instituto de Estudios Bercianos, 2006.

16. La titulación de este cartulario «Tumbo antiguo del anno de MCCIX» se debe a una mano de época moderna. Por encima de este título se consignó «Escrito enno anno do nacimiento do Señor de mil e docentos e nobe annos». Ya en el siglo XIX en el mismo folio hubo un intento de rectificación de esta información: «No pudo ser hasta pasado el año de 1283, como se ve por la escritura 375, entre otras, Y aún esto entiéndase sólo hasta el folio 94. Véase lo que dice S. P. Herrezuelo en las Memorias que escribió del monasterio al folio 225, o al 384 en la copia de las mismas Memorias».

17. El índice se contiene bajo el siguiente epígrafe «Estos son elo privilegios et elas cartas que son escriptas que jacen en este libro» y ocupa siete folios. Según Augusto Quintana, se redactó de forma paralela al cuerpo del cartulario por la misma mano. Ciertamente, la similitud en la letra de las dos partes es notable por lo que si no fue la misma mano la que elaboró ambas se trató de un trabajo muy próximo.

18. TVSP, $n^{\circ} 385$.

19. En el recto de la tercera hoja de guarda inicial se copió en sentido vertical, en el margen izquierdo del folio 
estado de conservación es bastante bueno salvo raras excepciones ${ }^{20}$. Este cartulario no es un ejemplar unitario ni en lo que se refiere a su composición material ni respecto al contenido de los textos que conserva. En primer lugar, la calidad del pergamino empleado es variable y algunos folios presentan rasgados y cortes de tamaño considerable ya existentes en el momento de la ejecución de la escritura. Con todo, la disposición de sus páginas manifiesta el estricto cumplimiento de la regla de Gregory. Asimismo, la distribución de los veinte cuadernos que componen actualmente su estructura, excluyendo las hojas de guarda, tampoco es uniforme:

* 9 quiniones: contienen desde el título hasta el folio 8o. El primero y tercero de estos cuadernos carecen de un folio, respectivamente. Los siete últimos cuadernos de este bloque presentan reclamo, con excepción del cuarto que en el margen inferior de su folio inicial y final muestra una representación de figuras femeninas que desempeñan la misma función.

* 2 cuaterniones: ff. 8I a 96. Estos cuadernos presentan reclamo.

* 2 terniones: ff. 97 a I07. El segundo cuaderno carece de un folio.

* I sixtinión: ff. Io8 a II8. Este cuaderno carece de un folio y presenta reclamo.

* I binión: ff. II9 a I22.

* I quinión: ff. I23 a I32. Este cuaderno era originariamente un sixtinión al que se le cortaron dos folios.

* I singulión + I folio: ff. I33-I35.

* I quinión: ff. I36-I45.

* I ternión: ff. I46-I5I.

* I singulión: ff. I52-I53.

La heterogeneidad es también la característica que define a este cartulario respecto a la distribución de sus elementos decorativos y a la disposición del texto. La decoración de este códice consiste en la alternancia de los colores rojo y azul para la composición de algunas iniciales y la elaboración de florituras en los márgenes de los folios. Se trata de una ornamentación vistosa aunque de factura poco delicada que, en algunos casos como, por ejemplo, la inicial del diploma de concesión de la villa de Pobladura de Valduerna por el rey Fernando Il resulta más esmerada $^{21}$. Este esfuerzo decorativo no se reproduce por todo el códice sino que se limita a la primera página del índice y desde el folio 2 recto al 94 recto, del ro8 vuelto al iıo recto, del in2 vuelto al iI4 vuelto y, finalmente, del iı6 vuelto al I3I

\footnotetext{
y con letra muy moderna la siguiente referencia «18.139.119. Esta cantidad de la izquierda tenía de renta anual este monasterio en tiempo de la Ley de Moisés» junto a la cual en sentido horizontal se encuentra un rúbrica con una distintiva «M». Por su parte, en el recto de la primera hoja de guarda final también con letra moderna se escribió en tres líneas diferentes «Ferndo VII, Fernando, Fernando VII».

20. Esta afirmación se refiere fundamentalmente al último cuaderno que presenta algunas manchas que impiden la lectura parcial de su contenido.

21. TVSP, $n^{\circ} 203$, f. 3 V.
} 
vuelto $^{22}$. Por su parte, las mayúsculas de los documentos copiados en el segundo cuaderno del tumbo se encuentran reforzadas o salpicadas por trazos de color rojo. La distribución del texto a lo largo del cartulario tampoco es uniforme puesto que se realiza a línea tendida hasta el folio io8 vuelto cuando comienza a redactarse a doble columna hasta el folio II4 vuelto, con ciertas excepciones. El índice y los textos fueron copiados en tinta negra empleando tinta roja para la numeración de los documentos, los regestos y algunas notas marginales. Respecto al índice, el primer epígrafe que contiene alude al privilegio de concesión del coto monástico por Ordoño Il y, originariamente, al margen de unas mínimas omisiones, finalizaba con el documento 379, copiado en el folio 94 recto. Sin embargo, una mano posterior incluyó otra referencia al documento identificado con el número 380 que alude al pleito que sostuvo la comunidad de monjes por el patronato de la capilla Domiz y que, en realidad, contiene varios diplomas concernientes al mismo asunto.

Por su parte, la numeración de los documentos se inicia con el número 2 en relación a un diploma del rey Fernando II de II64 copiado tras el privilegio de donación de Ordoño Il que inaugura el segundo cuaderno. Esta numeración, que alcanza hasta el documento 436 y contiene algunos errores de omisiones o duplicaciones, se consigna en caracteres romanos hasta el documento $20 \mathrm{I}$ inclusive, a partir del cual se ejecuta en caracteres árabes. Los regestos de color rojo finalizan en el decimoquinto cuaderno y coinciden, en lo general, con las entradas del índice hasta donde éstas alcanzan. El espacio a ellos destinado es muy variable, siendo claramente insuficiente en los cinco primeros cuadernos, y su elaboración parece deberse a varias manos que también se encargaron de la numeración de los documentos y de los topónimos que, generalmente, figuran al margen de cada texto en referencia a la ubicación de los bienes implicados en el mismo. Finalmente, la numeración de los folios se realizó con caracteres romanos, es claramente posterior a la composición del cartulario y comienza en el último folio del primer cuaderno. Parece elaborada por la misma mano que incorporó las correspondencias con los folios tras cada entrada del índice.

Por otra parte, como ha sido señalado, este cartulario es un corpus complejo en cuanto a su contenido debido a que éste puede dividirse, con ciertas limitaciones, en tres partes. En efecto, la primera parte del tumbo se inicia en el folio I recto y abarca hasta el folio 94 recto, incluyendo los primeros 379 documentos según la numeración del tumbo, y consiste en un corpus diplomático ordinario compuesto por donaciones, compra-ventas, permutas, confirmaciones, sentencias,

22. También se encuentran elementos decorativos en el diploma de convenio entre obispos y abades con el infante don Sancho de mayo de 1282, en el diploma de hermandad con este mismo infante en julio de 1282, en la concesión de heredad de Domingo García y su mujer en Llamas de Cabrera y, por último, en el reconocimiento de propiedades en Nancín del año 1378, aunque todos estos textos fueron incorporados al cartulario tras el cierre de su corpus primigenio. TVSP, núms. 47, 56 (segunda parte), 374 y 375. 
etc. La segunda parte del cartulario, que se extiende entre los folios io8 recto y I44 recto, comprende un inventario de propiedades del monasterio ordenadas según localidades, con sus límites y dedicaciones. La tercera parte dispuesta entre los folios I49 recto y I5I vuelto se titula «Estos son los yantares que usaron de longo tempore a darlos en Valdoza» y contiene información sobre los derechos y facultades del abad de San Pedro de Montes sobre los pobladores del valle de Valdueza, donde se afincaba el coto monástico. Algunos de los espacios intermedios a estas tres partes constitutivas contienen diplomas de diverso tenor mientras que otros fueron dejados en blanco. Es evidente que esta diversidad manifiesta se justifica, en buena medida, por las diferentes fases de confección que se revelan en este cartulario. Así, su estudio codicológico permite desvelar que los dos cuadernos que abarcan los folios 97 recto a I07 recto no pertenecen a su etapa de confección primigenia, al igual que los cuatro últimos cuadernos entre los que se copia la denominada tercera parte del tumbo. Consecuentemente, es necesario especificar que su fase primitiva de redacción se compone del índice y de los folios numerados del 2 recto al 94 recto y del Io8 recto al 132 recto. El análisis paleográfico y la fecha de los diplomas incorporados permiten datar este corpus primigenio a finales del siglo XIII, probablemente, en torno a I290; pese a las equivocadas anotaciones dispuestas junto al título anteriormente señaladas.

Esta parte primitiva fue escrita en letra gótica textual común por lo que, según revela el estudio paleográfico tanto en la forma de la escritura como en el uso de las abreviaturas, parece ser un único copista. La inclusión de las iniciales M. A. o M. P. en los márgenes de siete documentos, aunque con letra mucho más cursiva que su cuerpo textual, hizo pensar al editor del tumbo que representaba un testimonio de la identidad del copista anónimo que, en función de la probable fecha de su composición, determinó como el abad Marcos Pérez (I286-I295) ${ }^{23}$. Ésta es una atribución difícil de corroborar, si bien es bastante probable que, en relación a la cronología expuesta, este abab tuviese cierto grado de participación en la confección del cartulario, aunque fuese exclusivamente como autor intelectual del mismo. Con todo, tal y como señala Augusto Quintana ${ }^{24}$, el trabajo de este copista primitivo se caracteriza por su buena formación como calígrafo y por sus limitaciones como paleógrafo y latinista, lo que le llevó a cometer errores notables. A partir de su contribución, con independencia de la denominada tercera parte y de algunas series documentales incorporadas entre la primera y la segunda parte del códice que también se deben a un único copista ${ }^{25}$, la variedad es la característica que define los restantes textos copiados en el cartulario. Como

23. Este argumento encaja para Augusto Quintana no sólo con la cronología del mandato de este abad sino también con su conocido empeño en la protección de los bienes monásticos, ya desde que ocupó el cargo de mayordomo durante el abadiato de Juan Martínez (1274-1286). TVSP, pp. 18-20.

24. TVSP, pp. 14-15.

25. TVSP, pp. 32-33. 
ha sido apuntado, no sólo se añadieron cuadernos en la parte intermedia y final del corpus primigenio sino que los espacios en blanco de la primera redacción también fueron utilizados. Así, hubo diplomas anteriores a esta etapa primitiva incorporados posteriormente en el tumbo y otros documentos con fecha mucho más tardía también copiados en sus folios. En consecuencia, el TSPM en su estado actual constituye un complejo mosaico de contenido y letras que abarcan, fundamentalmente, hasta bien avanzado el siglo XIV y en el que se encuentra ejemplos de gótica cursiva fracturada o gótica cursiva precortesana, entre otros ${ }^{26}$.

ESTRUCTURA DEL TUMBO DE SAN PEDRO DE MONTES

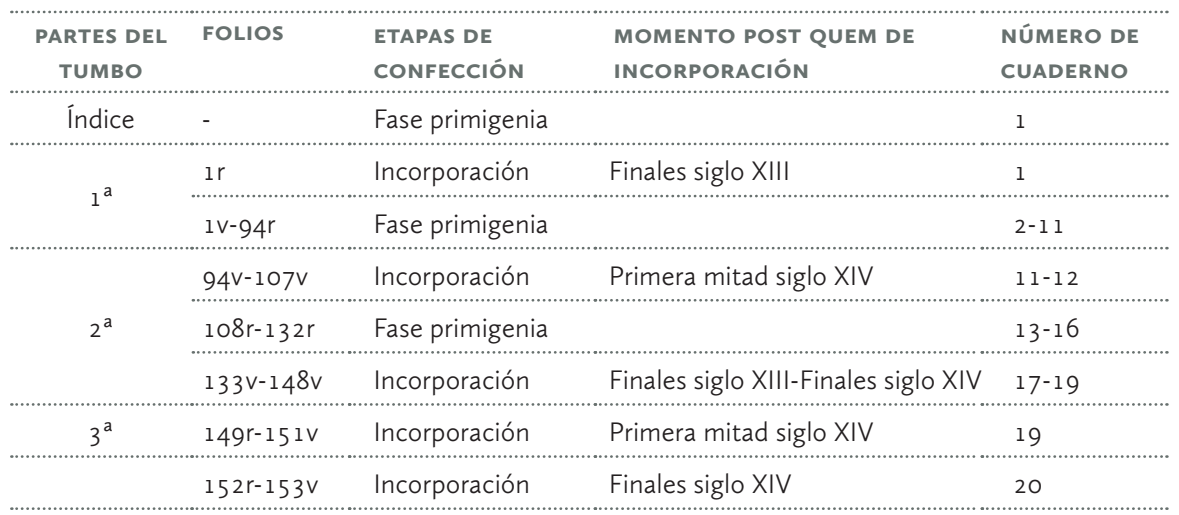

Por lo que respecta a la selección y clasificación documental que condiciona el discurso historiográfico propuesto en los folios de este códice diplomático es evidente que tanto su corpus primigenio como buena parte de las adiciones que contiene responden a un plan previo. Ninguna noticia tenemos acerca del archivo del monasterio de San Pedro de Montes ni de los diplomas que custodiaba por lo que el análisis de la estrategia de composición de este cartulario recae exclusivamente en lo deducible de su arquitectura. El copista primigenio incorporó más de cuatrocientos documentos de diverso tenor al tumbo. Sin embargo, y a pesar del considerable número reseñado, decidió excluir algunos diplomas especialmente relevantes tanto por su supuesta fecha de composición como por su contenido. Me refiero, fundamentalmente, a algunos de los documentos que hacen alusión a negocios destinados al monasterio por el obispo Ranulfo a finales del siglo IX $^{27}$.

26. Los textos más tardíos copiados en este cartulario se conservan en su último cuaderno, algunos de los cuales son ilegibles debido a su deteriorado estado de conservación. Entre estos documentos destaca la copia de una bula otorgada por el papa Bonifacio IX en el folio 153 recto o la transcripción de un epitafio situado en la claustra baja con fecha de 1434 escrito con letra muy moderna en el folio 153 vuelto.

27. TVSP, núms 2, 3 y 4 . Sin embargo, se incluyó en el folio 72 recto otro diploma emitido por Ranulfo por el que da la iglesia de Villanueva de Valdueza, $n^{\circ}$. 1. Sobre esta cuestión volveré más adelante. Ranulfo, obispo de Astorga (880-¿902?), era un aristócrata berciano muy próximo a la monarquía, que fue elevado al pontificado en la últimas 
Además, como apunta Augusto Quintana ${ }^{28}$, este copista incorporó un único documento referente al tiempo del abadiato de Marcos Pérez, una bula del papa Honorio IV del año I286 confirmando las posesiones del cenobio ${ }^{29}$. Esta limitación cronológica justificaría la exclusión de otros diplomas destacados como los otorgados por el rey Sancho IV entre los años I287 y I294 ${ }^{30}$.

En lo que se refiere al orden documental escogido, el criterio seleccionado fue el topográfico-geográfico, con excepción de los primeros nueve folios del cartulario que contienen, mayoritariamente, una serie de privilegios reales y pontificios que ilustran derechos y confirmaciones a favor del cenobio ${ }^{31}$. La ordenación geográfica que condicionó la primera parte del tumbo sirvió parcialmente de referencia para la segunda, aunque las incorporaciones posteriores desvirtuaron sustancialmente esta lógica formal. Por su parte, los diplomas incluidos en los primeros nueve folios, a pesar de que la confirmación del coto monástico por Sancho IV en I294 que ocupa el primero de ellos sea una incorporación posterior, no responden a ningún criterio definido con la salvedad de la relevancia de su contenido y de la inicial disposición de los privilegios regios respecto a los papales. La presencia de estos documentos en la parte inicial del cartulario nos informa de la importancia a ellos conferida en su producción. Respecto a los diplomas incorporados tras el corpus primigenio, y, fundamentalmente, con excepción de la denominada tercera parte que forma una narración coherente en sí misma, no existe un criterio de ordenación específico sino que su copia en el tumbo se explica en función del espacio disponible y de las ausencias detectadas por los copistas respecto a la parte primitiva ${ }^{32}$.

En cuanto al contexto de producción de este cartulario, su apertura coincide con una etapa de notable declive del dominio señorial de San Pedro de Montes que comienza con el reinado de Alfonso X (I252-I284) y se acentúa durante el mandato del abad $\operatorname{Marcos}^{33}$. Mercedes Durany apunta a que «aunque algunos problemas se

décadas del siglo IX por Alfonso III. Su presencia se menciona en le Crónica Albedense y en donaciones regía en los años 881 y 893 . Sus relaciones con el monarca empeoraron cuando apoyó a Vermudo Ordoñez en la sublevación contra el rey puesto que desde el año 893 deja de aparecer como confirmante en la documentación regía. Su cargo en la sede astorgana fue ocupado por Genadio con quien debió de mantener cierta rivalidad.

28. TVSP, p. 18. En el folio 135V se conserva una donación de propiedades en Villanueva de Valdueza por parte del abad Marcos con fecha de 1295 . TVSP, $n^{\circ} 386$. Según el editor, quien erróneamente localiza el diploma con el número 380 , aunque éste se copió tras el cierre del corpus primigenio debió ser el propio abad Marcos quien redactó el documento original. TVSP, pp. 20-21.

29. TVSP, $n^{\circ} 377$.

30. TVSP, núms. $374,375,378,379,381,383,384$ y 385 .

31. TVSP, núms. 6, 144, 195, 199, 203, 246, 267, 286, 290, 303, 307, 309, 325, 341, 350, 356, 363, 369, 371, 377 у 385 .

32. Así tal y como señala Quintana en alusión a las últimas relaciones contenidas en la segunda parte del tumbo «Da la sensación de que alguien notando que estos pueblos no estaban relacionados o que en ellos había más propiedades de las que habían sido consignadas, trató de completar la obra hecha, añadiendo por su parte estas notas finales». TVSP, p. 31.

33. Mercedes Durany establece que, a pesar de que el espacio del dominio de San Pedro de Montes se halla en fase de continuo crecimiento desde el último cuarto del siglo XI hasta mediados del siglo XIII, pueden identificarse las siguientes etapas en su formación y consolidación: fase de expansión del dominio en época de la reforma (1072-1100) en la que el monasterio logró el mayor volumen de tierras; fase de crecimiento en la primera mitad del siglo XII (11011150) durante la cual se siguieron incorporando a un ritmo más lento espacios jurisdiccionales; y fase de consolidación 
deben a factores externos parece ser que la mala gestión fue uno de los decisivos en su propia decadencia» ${ }^{34}$. Esto explica que en el año I266 la comunidad de monjes se viese obligada a realizar un convenio sobre el reparto de bienes entre el abad y los monjes ${ }^{35}$. La petición de privilegios y el posicionamiento en i282 de la comunidad monástica junto al infante don Sancho en la creación de una Hermandad opuesta a la autoridad de su padre Alfonso X son otros de los indicios identificados por esa autora como síntoma de la crisis del dominio ${ }^{36}$. En consecuencia, la producción del TSPM se revela como testimonio de las dificultades atravesadas por los monjes a finales del siglo XIII y de las estrategias emprendidas por los mismos como forma de reacción ante este contexto desfavorable. En estas circunstancias la realización de este códice diplomático fue asumida como la creación de un instrumento de gestión patrimonial pero también de recreación memorial ${ }^{37}$. Centrándonos, especialmente, en la segunda de las funciones señaladas, el análisis de este cartulario nos informa sobre los parámetros memoriales considerados válidos por los monjes para los propósitos proyectados en su confección a finales del siglo XIII. Además, la documentación conservada en sus folios nos permite la identificación de otro importante momento de forja de la memoria institucional del monasterio entre finales del siglo XI y principios del XII.

\section{LA FALSIFICACIÓN DEL PASADO LEJANO DEL MONASTERIO EN EL TUMBO DE SAN PEDRO DE MONTES}

Para facilitar la presentación de este análisis comenzaré por el primero cronológicamente de los momentos de creación de la memoria institucional del cenobio reivindicados mediante la producción del TSPM. Se trata de la campaña

\footnotetext{
entre mediados del siglo XII y XIII (1151-1250) en la que, aunque se produce alguna ampliación por las villas del camino de Santiago y tierras zamoranas, el monasterio consiguió sobre todo fortalecer las bases territoriales de su dominio. Durany, Mercedes, «San Pedro durante la Edad Media...», pp. 50-61.

34. Durany, Mercedes, «San Pedro durante la Edad Media...», p. 74.

35. TVSP, $n^{\circ}$ 357. La existencia de este convenio demuestra que no había sido respetada la división de mesas realizada a mediados del siglo XII y que el abad seguía siendo el principal beneficiario.

36. Desde el año 1251 en que Fernando III recibe la encomienda y defensa del monasterio eximiéndole de tributos y portazgos hasta el año 1294 en que Sancho IV confirma el privilegio de concesión del coto monástico de Ordoño II se suceden trece privilegios regios a favor de esta institución TVSP, núms. 309, 325, 338, 341, 350, 356, 369, 371, 375, 378, $379,381,383$ y 384 . Otros síntomas de declive señalados por Mercedes Durany y María del Carmen Rodríguez son la búsqueda de una mayor rentabilidad de los recursos lo que impulsa a los monjes a una especialización vitícola de las tierras con el fin de obtener excedentes comercializables; el ejercicio de un control sobre la mano de obra prohibiendo el abandono del coto monástico; la realización de un inventario a finales del siglo XIII con el objetivo de conocer el estado de los bienes y rentas; el endurecimiento del control señorial y la regulación de nuevos impuestos y, finalmente, la concesión del valle de Valdueza en encomienda a un miembro de la nobleza a cambio de protección. DuRANY, Mercedes y Rodríguez, María del Carmen, «El señorío de un monasterio berciano...», p. 358.

37. El propósito de gestión y defensa patrimonial que subyace en la confección de este códice se vislumbra no sólo por el esfuerzo de conservación documental que su confección supuso sino también por el orden geográfico seleccionado y por la preocupación de inventariar las propiedades monásticas manifiesta en su segunda parte.
} 
de recuperación del pasado lejano de la institución, el que se refiere a su etapa fundacional en los últimos años del siglo IX y los primeros del X, que tuvo lugar en el scriptorium monástico entre finales del siglo XI y principios del siglo $\mathrm{XII}^{38}$. Las estrategias de conservación de la nómina de diplomas falsos o interpolados resultantes de esa campaña de recreación memorial en el tumbo monástico no fueron uniformes. En efecto, el trabajo realizado en el corpus primigenio se caracteriza por una selección intencionada de esa serie documental que conllevó importantes descartes en la misma. Esta operación de exclusión del pasado lejano no se demuestra gratuita sino que, al igual que lo constatado en otros cartularios monásticos como el Becerro Segundo de Sahagún ${ }^{39}$, nos informa de los parámetros memoriales preferentes que guiaban la confección de este códice diplomático y de la falta de utilidad de dicho período fundacional para los propósitos ideados sobre el mismo. La conservación de los diplomas marginados en la parte primitiva se debe a una mano posterior que, ejecutando una de las muchas incorporaciones de las que fue objeto este cartulario, incluyó estos documentos en los folios en blanco disponibles. Por tanto, este ejercicio de recreación memorial no se corresponde con el momento de inicial producción del TSPM aunque su conservación en el mismo nos informa del valor de su recuperación para las exigencias demandadas a este instrumento por sus productores secundarios.

La nómina de diplomas sospechosos implicados en esa campaña de recuperación de la memoria fundacional del monasterio asciende a siete. Se trata de los primeros diplomas consignados según la edición del tumbo aunque su disposición real en el mismo no siempre es tan relevante. Los cuatro primeros hacen referencia a distintos negocios otorgados por el obispo de Astorga Ranulfo a favor del monasterio de San Pedro, el quinto y el séptimo recogen donaciones de otros cargos eclesiásticos menores al cenobio ${ }^{40}$ y el sexto contiene la famosa concesión del coto monástico por Ordoño $\mathrm{II}^{4 \mathrm{I}}$. De todos ellos, los seis primeros

38. Sobre las nociones de pasado lejano y cercano, y los usos de esta dimensión temporal en la Edad Media véase SOT, Michel, «Autorité du passé lointain, autorité du passé proche dans I' historiographie épiscopale (VIII - XI e siècle). Les cas de Metz, Auxerre et Reims», en SANSterRe, Jean-Marie (coord.) : L'autorité du passé dans les sociétés médiévales. Rome, École française de Rome, 2004, pp. 139-175.

39. Agúndez San Miguel, Leticia, op. cit., p. 50.

40. La presencia de estos cargos eclesiásticos como tempranos promotores del dominio monástico ha sido estudiada por Iñaki Martín Viso quien señala que un $67 \%$ de los actores que interactúan con San Pedro de Montes son de rango eclesiástico: «En San Pedro de Montes nos encontramos con la participación activa de miembros de la aristocracia, lo cual resulta muy evidente antes de 950, así como una baja presencia de la categoría «otros» y ninguna referencia a la monarquía. (...). Por consiguiente, parece que estamos ante un modelo de monasterios que tiene como agentes interactuantes fundamentalmente individuos con rango eclesiástico, lo que se adecua a un tipo de cenobios, cuyo prestigio procede de una supuesta renovatio de antiguos modelos de época visigoda». MARTín VISO, Iñaki, Monasterios y redes sociales..., pp. 21-22.

41. TVSP, $n^{\circ}$ 1: El obispo Ranulfo da la iglesia de Villanueva de Valdueza, (892,junio,5), f. 72 r; $n^{\circ}$ 2: El obispo Ranulfo da al monasterio la iglesia de Redelga, (892, noviembre,1), f. 106r; $n^{\circ}$ 3: El obispo Astorga Ranulfo da a los monjes la iglesia del propio monasterio, (895, septiembre,5), f. 106r-v; $n^{\circ} 4$ : El obispo Ranulfo consagra abad a san Genadio y dota al monasterio, (896, abril, 3), f. 105 r-v; $n^{\circ}$ 5: Los presbíteros Alvaro y Gutierre y el diácono Suero dan a san Genadio la iglesia de Redelga, (902, enero, 11), f. 46r; n 6:Ordoño Il da al monasterio el Coto de Valdueza, (918, abril, 24), f. 2r-v; n 7: El presbítero Ansemiro da al monasterio una iglesia en Turienzo de los Caballeros, (923, octubre, 28), f. 49r. 
son los más relevantes por la implicación de su contenido y solamente el primero, quinto, sexto y séptimo fueron copiados en la parte primigenia del códice. Las opiniones de los investigadores respecto a estos documentos han sido divergentes e incluso variables, así el propio Augusto Quintana modificaba su criterio acerca de la concesión regía rechazando definitivamente su autenticidad ${ }^{42}$. Por su parte, Mercedes Durany puso de relieve la existencia de la campaña de manipulación documental a finales del siglo XI o comienzos del XII y señaló que los cuatro primeros diplomas y el sexto son falsos mientras que el quinto y el séptimo están interpolados ${ }^{43}$. Según esta autora, además de los problemas en cuanto a la datación de estos documentos, manifestados por su editor, tanto su encabezamiento como su contenido formal no se corresponden con los de su pretendido momento de redacción. Así, por ejemplo, el segundo diploma cuestionado por el que la villa e iglesia de Santa María Alba de Redelga aparecen donadas por Ranulfo en el año 892 es, en realidad, una copia del quinto diploma sospechoso que recoge la donación de estos bienes por los presbíteros Alvaro y Gutierre y los diáconos Suero y Rodrigo al abad Genadio en el 902. No obstante, para tratar de salvar la incongruencia cronológica que la secuencia de estos negocios pretende implantar, este documento añade «sicut eam constestavit bobis Patri nostro domino Ranulfo episcopo post parte vestra et fratribus vestris sancti Petri», frase que, para Mercedes Durany, es sin duda es una interpolación de finales del siglo XI. Lo mismo sucede, en opinión de esta autora, con el séptimo de los diplomas analizados tanto en el encabezamiento como cuando se dice que la donación sirva para la luminaria de la iglesia y el estipendio de los pobres, «fuera de todo impedimento episcopal»-absque episcopali impedimento- lo que también es una interpolación posterior. Asimismo, el primer diploma por el cual Ranulfo dona al cenobio la iglesia de Santa María de Castrelo no sólo es confirmado por personajes cuya existencia se corrobora a finales del siglo XI, como Flagino Didaz, sino que su fórmula de destinatario es una excepción hasta la década de io8o y particularmente de 1090 cuando encuentra una gran profusión ${ }^{44}$. El contenido de esta fórmula hace referencia a dos cuestiones relacionadas entre sí y

42. Según este autor, las dudas se ciernen fundamentalmente sobre la concesión regía asumiendo la autenticidad del resto de documentos, pese a señalar ciertas incongruencias en los mimos. Sobre el diploma regio apunta «considero el documento totalmente falso. Con la escritura de Ranulfo por delante, alguien en el siglo XII amañó por completo una concesión real totalmente inexistente». TVSP, p. 90. Por su parte Antonio Linage, quien también reconoce la falsedad del diploma, señala «es el caso que cuando ya el documento está concluso (...) sigue un desdoblamiento del mismo, es decir, una segunda redacción, sustancialmente idéntica, pero con la variante esencial de que no coinciden los otorgantes, pues la real pareja ha sido sustituida por el propio obispo de Astorga, Ranulfo», "Creemos que estas observaciones son más a tener en cuenta en un documento como éste que se nos presenta con dos incompatibles redacciones y del que no podemos (...) descartar que ha sido objeto de una refundición posterior en alguna de ellas, o acaso en ambas». LiNAGE CONDE, Antonio, Los orígenes del monacato benedictino en la Península lbérica, Tomo Il, León, Centro de Estudio e Investigación San Isidoro, 1973, pp. 709-712.

43. DuRAny, Mercedes, San Pedro durante la Edad Media..., p. 39.

44. TVSP, $n^{\circ}$ 1: Sanctissimo domino et patrono meo fortissimo venerabilior apostolorum princeps Petro, Christi Ecclesie columpna, cuis basselica sita essedignoscitur inter Alpes bergidenses ad radice montis qui vocatur Aquiliana ubi ex cenbobio regule constructum est permnendum (...). Entre los años 1080 y 1100 se conservan 77 diplomas de los cuales más del $33 \%$ 
extraordinariamente relevantes en la historia del monasterio entre los años finales del siglo XI y los primeros del XII: la advocación exclusiva del cenobio a San Pedro y la convivencia de los monjes bajo una regla.

El primero de los asuntos señalados hace referencia a la unificación definitiva de las diferentes basílicas que conformaban el primitivo conjunto monástico ${ }^{45}$. Sobre este tema también nos informa el segundo documento sospechoso por el que la donación episcopal se realiza a los «patronos sancto Petro apostolo et sancte Crucis», cuyas basílicas están en el lugar que llaman Aquiliana. Así el texto recoge, como apunta Mercedes Durany, «Y para que por mi devoción no sólo se mantengan, sino que salgan de la pobreza, las santas iglesias que están fundadas en el predicho lugar (...) un poco por deseo propio decidí llevarlas a un mismo sitio (...) que el sacerdote de la santa iglesia vuestra cogiese las casas que sean de vuestro derecho perpetuo y las haga asociarse con firmeza» ${ }^{46}$. Esta información se completa en el tercer documento cuestionado cuando se expone que Ranulfo ha querido edificar un monasterio de monjes, a los que concede la iglesia de San Pedro, que se halla entre los montes Aquiliana, Rufiana y Peñalba. La donación se hace «cum omni suo edificio quidquid ibídem factum est aut factum fuerit». En ambos casos se trata de atribuir a Ranulfo la decisión de unificar las basílicas existentes y la erección de un edificio cenobítico principal aunque, según consta en los documentos supuestamente posteriores a éstos, la realidad del conjunto monástico era muy diferente ${ }^{47}$.

La consecución definitiva de este objetivo no debió de producirse hasta mediados del siglo XII aunque los primeros intentos comienzan a documentarse durante el tiempo de la reforma ${ }^{48}$. En efecto, con fecha de junio de I072 se conserva un documento por el que Pascual, abad de Santiago de Peñalba y posteriormente de San

\footnotetext{
contienen esta fórmula de destinatario. Anteriormente, también se registra en el documento $n^{\circ} 18$ según la colección con fecha de 1055, aunque se trata de un diploma con problemas de datación.

45. Esta característica se relaciona con la tradición visigoda de vida eremítica que supuso el inicio de este cenobio y que se mantuvo durante la época de san Genadio quien, como señala Mercedes Durany, «aceptó y supo conjugar (...) la existencia de monjes anacoretas y cenobitas en aquellos parajes. Ello explica que el conjunto monástico de esta época se asemeje en gran medida al de época visigoda (...). Cuevas y celdas de anacoretas dispersas por los montes Aquilianos y proliferación de «iglesias» y «oratorios» que se van levantando también en las inmediaciones de las celdas de estos monjes. Algunas mantuvieron vida propia y otras acabaron integrándose en el monacato cenobítico». Esto es lo que sucedió, por ejemplo con la ermita de la Santa Cruz fundada por Saturnino en época visigoda y que recibió en el siglo X nuevas dedicaciones. Además de esta ermita y la propia iglesia de San Pedro había otras dos: la de San Martín y la de San Ciprián, situadas no muy lejos de las anteriores. «Aunque todas ellas tienen carácter exento, en su conjunto conforman el monasterio de Montes, tal y como se constata en el encabezamiento de los documento del Tumbo a partir del año 923: patronis Sanctorum apostolorum Petri et Pauli, sancti Martini,sancti Cipriani sive venerandis reliquis sancte Crucis, quorum baselice site sunt. (...)». DuRAnY, Mercedes, San Pedro durante la Edad Media..., pp. 43-44. 46. Ibidem, p. 40.

47. Según Mercedes Durany, pudiera ser que Ranulfo, tras su alejamiento del obispado y de la corte, restaurase o participase de alguna manera en la restauración de la basílica de la Santa Cruz lo que le permitió aparecer posteriormente como el fundador del monasterio. Ibidem, p. 41.

48. Ibidem, p. 63. Según esta autora, la aceptación, al menos desde el punto de vista conceptual, de esta realidad unificada debió de producirse durante el abadiato de Pedro (1137-1152), cuando se puede afirmar que el cenobio es una entidad benedictina independiente.
} 
Pedro, hace un pacto con este cenobio ${ }^{49}$. Este interesante diploma nos presenta una configuración espacial del conjunto monástico semejante a la expuesta durante las décadas anteriores. En consecuencia, el objetivo del abad es plantear una necesidad de reforma unificando las basílicas existentes en una sola y obligando a los monjes a llevar una vida en común. Como señala Mercedes Durany ${ }^{50}$, desde el año I08I los diplomas, aunque no de forma absoluta, comienza a emplear el término baselica con infinitivo sita ese cuando se pretende hacer referencia a una sola iglesia que alberga las reliquias de los santos en un cementerio en común. A comienzos del siglo XII estos documentos recogen expresiones de la basílica con el verbo en singular y no en infinitivo, lo que supone el triunfo de un monasterio formado por una sola iglesia. En consecuencia, pese al esfuerzo de temprana y prestigiosa atribución a Ranulfo de la unificación del conjunto monástico realizado en la campaña de manipulación documental cuestionada son los propios diplomas los que contradicen esta información y la sitúan en la época de la reforma.

El segundo asunto analizado dentro de esta nómina de diplomas sospechosos alude a la observancia de la regla monástica, más en concreto a la aceptación de la regla benedictina. La referencia a la norma casiniense aparece en el cuarto diploma señalado donde se recoge que el obispo Ranulfo consagra como abad del cenobio a Genadio, le da la regla de San Benito y le concede sus derechos sobre el valle de Valdueza en el año 896, y también en el sexto documento por el que Ordoño Il concede el coto monástico en el 9I8. Ambos documentos se encuentran estrechamente relacionados dado que comparten literalmente buena parte de su cuerpo textual. La mención expresa a la regla benedictina en el diploma regio ha sido analizada por Antonio Linage quien reconoce su falsedad para la pretendida fecha del diploma ${ }^{51}$. Además, la falta de alusiones a la misma en la documentación monástica hasta el año Io82 plantea importantes reticencias para su aceptación en los dos diplomas referidos ${ }^{52}$. En efecto, Artemio Martínez ha profundizado en

49. TVSP, $n^{\circ} 21$. Según Juan Antonio Testón, este diploma pudiera hacernos pensar en una confederación monástica entre San Pedro de Montes y Santiago de Peñalba por la debilidad de este último cenobio. Según este diploma, Pascua entrega ornamentos para la iglesia, libros y utensilios, además de otras posesiones familiares en Priaranza, Entre los firmantes del documento se encuentra el prepósito de san Pedro, Imila. Para este autor, la concesión de este diploma pudo deberse al intento de introducir la regla de San Benito y el hecho de citar a los prepósitos puede ser un signo claro de la penetración de la norma en la comunidad. TeSTón TUERIEL, Juan Antonio, op. cit., pp. 324-325.

50. Durany, Mercedes, San Pedro durante la Edad Media..., p. 63.

51. «Salta a la vista que las menciones de la observancia monástica en ambas versiones [refiriéndose a las contenidas en el propio diploma regio] son demasiado reiterativas y que las viejas fórmulas alternan con las citas de RB en una vecindad extraña, pues no se trata solamente de fórmulas anodinas que por inercia viniesen arrastrándose después de la benedictinización (...), sino de expresiones concretas del antiguo régimen del códice abacial, lo cual no puede regatearse al «abbatis oficiositate munerimos, data regule santeoservantis» de la redacción episcopal. Por otra parte, es curioso cómo el párrafo de la mención benedictina es coincidente del todo en las dos... y cómo de las dos podría suprimirse sin detrimento, es decir, que la verosimilitud de la interpolación del mismo no es discutible», «Y no ocultamos que el descubrimiento por Quintana de la donación episcopal precedente no hace sino abonar que la refundición posterior no sea sino una falsificación total, con la evidente intención de amplificar los términos de liberalidad y revestirlos de la sanción regia». LINAGE CONDE, Antonio, op. cit., pp. 711-712.

52. La primera mención a la observancia de la regla casiniense en este cenobio, al margen de los diplomas cuestionados, se conserva en un diploma con fecha de 25 de mayo de 1083 por el cual el presbítero Jimeno concede 
este tema contextualizándolo entre todas las implicaciones derivadas del proceso de reforma en este monasterio ${ }^{53}$. Como este autor manifiesta, la existencia de un cisma en la comunidad monástica desde el año I082 hasta su resolución definitiva en torno al año Iog6 es síntoma de la divergencia de opiniones ante la reforma ${ }^{54}$. Parte de la comunidad se opuso a los cambios derivados de este proceso y la presencia del obispo astorgano Pedro Nuñez, tras su expulsión de la sede por su negativa al cambio de rito en la asamblea de Burgos de Io80, supuso un importante apoyo a esta facción tradicionalista; especialmente desde su nombramiento como abad en Io82.

Como señala Mercedes Durany, la constatación de este cisma en el cenobio no se refiere sólo a la presencia de dos abades con sus respectivos partidarios y a la demostración de enfrentamientos entre los monjes ${ }^{55}$, sino a los esfuerzos de manipulación de la realidad transmitidos por la documentación. Efectivamente, según esta autora, el grupo tradicionalista simula la aceptación de los principios reformadores ante el rey, «de ahí, que en el año Io82 se encuentre en el Tumbo la primera mención a la Regla de S. Benito si bien en la misma frase se alude al viejo codex regularum, es decir, a la norma del abad $»^{56}$. Otro testimonio de este intento de engaño es la presencia, contraria a la norma benedictina, de dos priores en el cenobio desde el año I09I ${ }^{57}$. Para Mercedes Durany, «más que confrontación, que también la hubo desde luego, habría que hablar de una situación anómala en $\mathrm{S}$. Pedro de Montes, ya que se convierte en un bastión defensor del inmovilismo, de la tradición, bajo la apariencia formal, reflejada en sus escrituras, de que se ha aceptado la reforma» ${ }^{5}$. Por su parte, Artemio Martínez recoge las posibles causas de esta enconada resistencia y alude al interés manifestado por una parte de la comunidad en mantener su independencia frente a Cluny y al fuerte asentamiento

posesiones en Merayo. TVSP, $n^{\circ}$ 34: «Familiares qui ibídem sunt conmorantium sub norma regule Benedicti». En este documento también se informa sobre la llegada del ex obispo astorgano Pedro Nuñez al monasterio y sobre su elección como abad: «Jam sunt duo annis qui depositus est Petrus episcopus de ipsa sede astoricense ab ipso príncipe qui desursum resonat in cenobio sancto Petro (...)».

53. Martínez Tejera, Artemio, Cenobios leoneses altomedievales..., p. 93.

54. Para saber más sobre este cisma véase, TVSPM, pp. 45-53. Tras el fallecimiento del abad Pascual en 1096 se constata la única presencia del abad Pelayo Romaiz, elegido en 1093 y de talante reformista. En mayo de 1099 parece finalizado el cisma según recoge un documento: «(...) reget ecclesiam sancti Petri et cunctum fratum abbas dominus Pelagius in istis temporibus permanet securus». TVSP, $n^{\circ}$. 104. Para conocer la amplitud del fenómeno de reacción ante los cambios reformistas y el surgimiento de nuevas dependencias véase, REMENSNYDER, Amy, Remembering Kings Past. Monastic foundation Legends in Medieval Southern France, Cornell University Press, Ithaca, 1996, pp. 215288; Vanderputten, Steven, Reform, Conflict, and the Shaping of Corporate Identities, Collected studies on Benedictine Monasticism 1050-1150, Munster, Lit Verlang, 2013.

55. Durany, Mercedes, La región del Bierzo en los siglos centrales de la Edad Media, 1070-1250, Santiago de Compostela, Universidad de Santiago de Compostela, 1989, p. 57. Se trata de un documento con fecha debatida, 1096 o 1106, que expone como Rodrigo Buisañez, monje-sacerdote del cenobio, fue brutalmente agredido por los monjes «conservadores» cuando volvió al cenobio tras un viaje a Roma. Para conocer la lista cronológica de los abades que se sucedieron en este periodo de duplicididad en el mandato véase TVSP, p. 53.

56. Durany, Mercedes, San Pedro durante la Edad Media..., p. 51.

57. TVSP, $n^{\circ}$ 53: «Oramius prior, cnf. Guterus, prior, cnf.». La existencia de estos dos priores puede ser testimonio de la falta de unificación de las basílicas.

58. Durany, Mercedes, San Pedro durante la Edad Media..., p. 51. 
del eremitismo en la casa desde su época fundacional. «Aspectos fundamentales en la tradición espiritual y legislativa de Montes y básicos en su discurrir diario (además del eremitismo, la dependencia jurisdiccional del obispo -episcopi sub regula - y el Federacionismo), pretendían ser eliminados de repente, sin la transición necesaria para la adaptación (...)»59.

El análisis de la documentación monástica conservada del período de la reforma nos informa de otro parámetro memorial reivindicado durante esta etapa. Se trata de la recuperación de las tres figuras de los hombres santos que lideraron la etapa fundacional del monasterio: Fructuoso, Valerio y Genadio ${ }^{60}$. En efecto, la mención conjunta de estas tres figuras en las fórmulas de destinatario no se produce hasta la década de $1080^{61}$, constatándose anteriormente tan sólo la referencia a Fructuoso, fundador del cenobio. Según Iñaki Martín Viso, quien ha estudiado la memoria de estos santos, la alusión a Fructuoso pretendía reforzar el prestigio de la institución debido a su condición de fundación propia. Con todo, este autor subraya la insistencia de los diplomas en definir anacrónicamente a Fructuoso como obispo, lo que entronca, en su opinión, con el patronazgo que ejercían los prelados astorganos sobre este monasterio ${ }^{62}$. Además, este autor señala que la aparición de las fórmulas que se refieren a la triada santa coincide con el momento en el que San Pedro de Montes adquirió la condición de principal monasterio de la región en un proceso generalizado de jerarquización de los dominios monásticos que se produjo en los reinos de León y Castilla ${ }^{63}$. Así, la elección de la nueva fórmula encubre una modificación en la articulación de la memoria que pretende reforzar el prestigio de la institución mediante el recuerdo de todas las figuras santas vinculadas con su etapa inicial y el supuesto patronazgo episcopal que éstas proporcionaron al cenobio ${ }^{64}$.

59. Martínez Tejera, Artemio, Cenobios leoneses altomedievales..., pp. 94-95.

60. Para conocer más sobre estas tres figuras véase, MARTín VISO, Iñaki, La memoria de los hombres santos..., pp. 440-450.

61. «Sanctissimo domino et patrono meo ac post Deum mihi fortissimo venerabilitor apostolorum prinicpi Petro, Christi Ecclesie columpna, cujus baselica sita esse dignoscitur inter Alpes bergidenses ad radicem montis que vocatur Aquiliana, ubi ex cenobio monastice regule constructum est permanendum, a sanctis Patribus Fructuosus, Valerius et Genadius (...)». Esta es la fórmula más generalizada que hace referencia a estos hombres santos. Entre los años 1081 y 1100 más del $37 \%$ de la documentación contiene esta referencia. En escasas ocasiones se invierte el orden de los personajes, situando a Genadio por delante de Valerio.

62. Martín VISO, Iñaki, La memoria de los hombres santos..., p. 458. Ciertamente, el amago de atribuir la fundación del cenobio a Fructuoso obispo es una interpretación un tanto anacrónica puesto que su designación como obispo de Dumio en el año 653 fue posterior a este suceso.

63. García de CorTÁzAR, José Ángel, «Los monasterios del reino de León y Castilla a mediados del siglo XI: un ejemplo de selección de las especies», en GARCíA DE CorTÁZAR, José Ángel (coord.): Monjes y monasterios hispanos en la Alta Edad Media, Aguilar de Campoo, Fundación Santa María la Real, 2006, pp. 255-288.

64. Por otra parte, como señala Iñaki Martín Viso, «si en 1075, Genadio y su memoria aparecían directamente relacionados con el monasterio de Santiago de Peñalba, en el primer cuarto del siglo XII se le menciona fundador de San Pedro de Montes, e incluso aparece en solitario. Puede decirse que el antiguo obispo de Astorga adquiere en esos momentos un importante papel en la memoria del monasterio lo que coincide con una progresiva decadencia de la importancia de Santiago de Peñalba. Posiblemente, la memoria de Genadio y de su actividad se desplaza ahora en beneficio de San Pedro de Montes». Martín Viso, Iñaki, La memoria de los hombres santos..., pp. 458-459. 
A pesar de que este nuevo parámetro memorial no se encuentra en ninguno de los diplomas sospechosos analizados, la recuperación de estos hombres santos $\mathrm{y}$, especialmente, la reiteración de los vínculos establecidos con el episcopado por mediación de estas figuras coinciden con el propósito de elaboración de estos documentos espurios en opinión de Mercedes Durany. En efecto, para esta autora estos documentos fueron elaborados «(...) para justificar los derechos del episcopado astorgano sobre el monasterio, lo cual no significa que no contengan información histórica de interés y veraz sobre estos primeros años de la décima centuria» ${ }^{65}$. Este argumento enlazaría con el interés de estos diplomas por ensalzar la figura del obispo astorgano Ranulfo como protector del monasterio. Ciertamente, y en contradicción con otras fuentes monásticas que otorgan a Genadio el protagonismo como artífice de la restauración del monasterio ${ }^{66}$, estos documentos tratan de atribuir la mayor parte del mérito a este obispo. Para Mercedes Durany, «no se debe descartar la hipótesis de que el obispo, tras su alejamiento de la corte, se trasladase al valle de Valdueza, y emprendiese algunas acciones paralelas a las de Genadio. Así, al tiempo que éste restaura el monasterio de S. Pedro de Montes en el 895, Ranulfo debió de restaurar o participar de alguna manera en la restauración de la basílica de la Sta. Cruz, lo que le permitiría aparecer después como el fundador del monasterio, y el promotor de la fusión de las dos iglesias» ${ }^{67}$.

Con todo, la recuperación de las figuras de Ranulfo y Genadio desde su posición episcopal nos informa del interés manifiesto por resaltar los privilegiados vínculos del cenobio con este poder durante el periodo de la reforma, pese a las contradicciones manifiestas $^{68}$. En consecuencia, este esfuerzo de justificación de la dependencia jurisdiccional del obispo astorgano se concibe como una forma de protección ante los cambios introducidos por la reforma y como un intento de reivindicación de la independencia del cenobio frente a la intervención de otros poderes. Me refiero, particularmente, al poder regio personificado en la figura de Alfonso VI quien, como apunta Artemio Martínez, puso un inusitado empeño en hacer triunfar el programa reformista en San Pedro de Montes «por el importante

65. Durany, Mercedes, San Pedro durante la Edad Media..., p. 39.

66. El reconocimiento de Genadio como restaurador del cenobio se debe a un diploma del año 915 conocido como su testamento en el que nos informa que procedente del monasterio de Ageo y con la ayuda de doce fratribus restauró este cenobio, fundado por Fructuoso y habitado por Valerio. Otro testimonio que confirma esta posición es la lápida de consagración de la iglesia de Montes que recoge «(...) Genadio, presbítero, con doce fratribus lo restauró en el año 895. Una vez hecho obispo, lo erigió de nuevo desde sus cimientos admirablemente como se observa, no mediante la opresión del pueblo, sino con gran costo y sudor de los monjes de este monasterio. Fue consagrado este templo por cuatro obispos: Genadio astoricense, Sabarico dumiense, Fruminio legionense y Dulcidio salamanticense, el 24 de octubre del año 919». Gómez Moreno, Manuel, Catálogo monumental de España. Provincia de León. León, Instituto Leonés de cultura, 1908, p. 130.

67. Durany, Mercedes, San Pedro durante la Edad Media..., p. 41.

68. Como señala Iñaki Martín Viso, a partir de 1156 se detecta un abandono en esta estrategia y, pese a la disminución del número de donaciones al monasterio, aún se conservan las suficientes, según este autor, como para considerar que estamos ante una nueva tendencia. MARTín VISO, Iñaki, La memoria de los hombres santos..., p. 459. Puede que este cese en las menciones a la triada santa a mediados del siglo XII se deba a que el cenobio se ha convertido ya en una entidad benedictina independiente. 
papel que esta casa desempeñaba en la comarca berciana y por tratarse de un baluarte de la tradición monástica hispana (...). Introducir la reforma en Montes, pensaría Alfonso VI, era el primer paso a dar, y fundamental, para la renovación cenobítica berciana, y por extensión en la parte leonesa de su reino (... $)^{69}$ ».

\section{LA EXALTACIÓN DEL PASADO PRÓXIMO DEL MONASTERIO EN EL TUMBO DE SAN PEDRO DE MONTES}

Como ha sido señalado, la recuperación del pasado lejano del monasterio mediante la incorporación de la nómina de diplomas sospechosos analizados recibió un tratamiento heterogéneo y, salvo la concesión regia de Ordoño II, no prioritario en la confección del TSPM. Este diploma falsificado, máximo garante de los derechos históricos de la institución, ostentaba originariamente la apertura del tumbo en un ejercicio de exhibición de las pretensiones monásticas también constatado en otros cartularios hispanos como, por ejemplo, el Becerro Gótico de San Pedro de Cardeña y la espuria delimitación del término monástico por García Fernández en el año 972 o el caso de los Votos en el Becerro Galicano de San Millán de la Cogolla ${ }^{70}$. Consecuentemente, la estrategia discursiva manifiesta en la sección liminal de este producto escriturario se decanta por la exaltación del pasado próximo de la institución. Así, la confección de este tumbo nos informa de la actualización de los parámetros memoriales empleados por los monjes en el nuevo contexto de debilidad de su poder que supusieron los años finales del siglo $\mathrm{XIII}^{71}$. La selección documental dispuesta en los nueve primeros folios de este cartulario, formada en su mayoría por diplomas regios y pontificios, representa un ejercicio de demostración de los vínculos más prestigiosos que el cenobio mantiene con las autoridades, muy común en la producción de cartularios monásticos como ejemplifica, entre otros, el Becerro Gótico de Sahagún ${ }^{72}$. Efectivamente, veinte y uno

69. Martínez Tejera, Artemio, Cenobios leoneses altomedievales..., pp. 93-94.

70. Martínez Díez, Gonzalo, Colección documental del monasterio de San Pedro de Cardeña, Caja de ahorros del círculo católico de obreros de Burgos, Burgos, 1998, n 158; GARCíA DE CORTÁZAR, José Ángel, «La construcción de la memoria histórica en el monasterio de San Millán de la Cogolla (1090-1240», en CORDERO RIVERA, Juan (coord.): Los monasterios riojanos en la Edad Media: historia, cultura y arte, Logroño, Ateneo riojano, 2005, p. 79; PETERSON, David, op. cit., pp. 666-669; García Andreva, Fernando, El Becerro Galicano de San Millán de la Cogolla. Edición y estudio, Logroño, Cilengua, 2010, pp. 36-38.

71. Un cambio en las pautas de identificación institucional que Francisco Javier Peña Pérez considera generalizado para la mayoría de los centros benedictinos durante el siglo XIII, debido a una crisis estructural profunda, y que ejemplifica con la fijación dominante de la memoria histórica del Cid en el monasterio de San Pedro de Cardeña, por encima de otros relevantes personajes o leyendas vinculados al cenobio como el abad Sisebuto o los doscientos mártires. PEÑA Pérez, Francisco Javier, «La creación de memoria histórica: San Pedro de Cardeña», en GARCía de Cortázar, José Ángel (coord.): Los grandes monasterios benedictinos de época románica (1050-1200), Aguilar de Campoo, Santa María La Real, 2007, pp. 225-230.

72. Los dos primeros cuadernos de este cartulario se destinan a la copia de los más destacados privilegios papales y reales supuestamente obtenidos por la comunidad monástica como muestra de su estrecha relación con estos poderes. Agúndez San Miguel, Leticia, op. cit., pp. 46-50. 
son los diplomas copiados en estos folios: dieciséis privilegios reales, tres papales, una concesión abacial y una sentencia del maestre Fernando ${ }^{73}$; si bien, como ha sido apuntado, el diploma de confirmación del coto monástico por Sancho IV en I294, que inaugura actualmente el tumbo, es una incorporación posterior a la confección primitiva del mismo.

Por su parte, la distribución cronológica de estos diplomas iniciales muestra una particular atención por los siglos XII y XIII, especialmente por la segunda mitad de esta centuria, lo que puede considerarse una evidencia del marco temporal de referencia que guiaba las intenciones de producción de este cartulario ${ }^{74}$. Con todo, es necesario señalar las limitaciones que esta observación conlleva debido a la escasez porcentual que esta tipología de privilegios regios y papales representa en la colección documental del cenobio. En efecto, al contrario que otros monasterios leoneses que fueron tempranamente objeto de la intervención regia y papal, en buena medida debido a sus propios orígenes fundacionales ${ }^{75}$, San Pedro de Montes evidencia una notable carencia en la recepción de este tipo de documentos $^{76}$. Esta es una restricción considerable para el trabajo de selección documental propuesto en los primeros folios del tumbo si bien el aumento de la demanda por parte de la comunidad monástica de este tipo de privilegios es síntoma de la crisis del poder monástico, especialmente desde la mitad del siglo XIII77 . La disposición de esta serie de diplomas regios y papales manifiesta el interés

73. Según el orden del cartulario: TVSPM, $n^{\circ} 385$, Sancho IV confirma el privilegio de Ordoño II a favor del monasterio; $n^{\circ}$ 6, Ordoño II da al monasterio el coto de Valdueza; $n^{\circ}$ 199, Privilegio de Fernando II por el que da al monasterio la iglesia de San Pelayo en Morales de Rey; $n^{\circ}$ 144, Alfonso VII confirma los privilegios reales del monasterio; $n^{\circ} 325$, Privilegio de Alfonso X confirmando la posesión de Morañes de Rey; $n^{\circ} 203$, Privilegio de Fernando II por el que da al monasterio la villa de Pobladura de Valduerna; $n^{\circ} 195$. Privilegio de Fernando II por el que confirma la donación de Ordoño II y declara «casa regia» a ésta de san Pedro; $n^{\circ} 369$, Alfonso X confirma el privilegio de Fernando II de 1162 ; $n^{\circ} 290$, Alfonso IX confirma la posesión de la iglesia de Morales; $n^{\circ} 246$, Alfonso IX da al monasterio la iglesia de Santa María de Palacios de Rey; $n^{\circ} 371$, Alfonso X exime de tributos al monasterio de Montes: $n^{\circ} 341$, Alfonso X exime de tributos las propiedades del monasterio en Morales de Rey; $n^{\circ}$ 307, Fernando III toma bajo su protección el monasterio; $n^{\circ} 309$, Fernando III exime de tributos y portazgos a San Pedro de Montes y a San Román de la Hornija; n³ 356, Alfonso X confirma la exención de portazgo a favor de Montes; $n^{\circ}$ 286, el abad Nuño concede fueros en San Román de la Hornija; $n^{\circ} 350$, sentencia del rey Alfonso X sobre unas propiedades en San Román de la Hornija; $n^{\circ} 363$ Sentencia en una querella sobre propiedades en San Román de Hornija; $n^{\circ} 267$, Bula pontificia de Inocencio III confirmando las propiedades del monasterio; $n^{\circ} 377$, Bula pontificia de Honorio IV confirmando las posesiones del monasterio y $n^{\circ} 303$ Breve del papa Inocencio IV.

74. Exactamente la distribución cronológica de estos diplomas, excluyendo el diploma confirmatorio de Sancho II, es la siguiente: primera mitad siglo X, 1; primera mitad siglo XII, 1; segunda mitad siglo XII, 4; primera mitad siglo XIII, 3; segunda mitad siglo XIII, 11.

75. Sobre este tema véase MARTín VIso, Iñaki, «Monasterios y redes sociales...», pp. 9-38.

76. Así entre los trescientos ochenta y seis documentos consignados hasta el año 1300 según la edición del tumbo como de tenor ordinario, y al margen de los seis diplomas excluidos de la producción del corpus primigenio cuyo otorgante es Sancho IV, tan sólo encontramos dos diplomas procedentes del entorno de la familia regia que no fueron incluidos en los folios iniciales. Se trata de una donación con fecha de 1150 por la que la infanta doña Elvira, señora de Cabrera, concede la villa de Noceda a san Pedro de Montes y otro documento del año 1257 del rey Alfonso $X$ por el que exime de tributos al cenobio. TVSP, núms. 171 y 338. La exclusión del diploma regio de la producción se deba probablemente a la repetición de su contenido en otro diploma de este monarca del año 1277. También tenemos noticia de la concesión en 1124 del priorato de San Román de la Hornija por la reina Urraca aunque este diploma no se conserva en la colección diplomática como tampoco debía conservarse ya en época del abad Marcos.

77. Así, por ejemplo, como señala Mercedes Durany la petición al rey Sancho IV del nuevo envío de los privilegios 
en la producción de este cartulario por ensalzar el patronazgo ejercido por estas dos autoridades sobre el mismo, en detrimento de los grupos y poderes cercanos opuestos al dominio monástico. Así, como apunta Iñaki Martín Viso, «se llega a la paradójica conclusión de que la larga y prestigiosa historia del monasterio, que incluía su restauración por Genadio y la dotación del obispo Ranulfo, no representaba el mayor aval para el monasterio a finales del siglo XIII» ${ }^{78}$.

Ya se ha señalado que no existe ningún criterio de ordenación definido de esta serie de diplomas iniciales, con la salvedad de que primero se transcriben los diplomas regios y después los pontificios. No obstante, su destacada ubicación nos informa de la lógica funcional que guió la confección de este proyecto respecto a su discurso de apertura ${ }^{79}$. En primer lugar, destaca la defensa del coto monástico situado en el valle de Valdueza que, según los documentos conservados, había sido donado al monasterio en el año 9I8 por el rey Ordoño $\mathrm{Il}^{80}$. La redacción de este documento apócrifo trataba de justificar el origen de la jurisdicción señorial aunque parece que ya a finales del siglo IX el coto monástico estaba limitado y Genadio disfrutaba de cierta autoridad en la gestión de este espacio. Las confirmaciones de esta concesión de inmunidad por Alfonso VII en II29 y Fernando II en II62 también reciben una atención prioritaria en los folios iniciales del TSPM ${ }^{81}$. Podría pensarse acertadamente que como instrumento de descripción y justificación del dominio monástico es razonable que estos documentos figuren al inicio del cartulario. Sin embargo, su ubicación privilegiada también pudiera deberse a los enfrentamientos que, desde principios del siglo XIII, la comunidad de monjes mantuvo con la Orden del Temple, con el monasterio vecino de Santiago de Peñalba y con los propios agentes reales en torno a la jurisdicción de este territorio ${ }^{82}$.

en cuero debido a la fragilidad del papel es indicio de las dificultades atravesadas en este periodo. DURANY, Mercedes, San Pedro durante la Edad Media..., p. 75.

78. MarTín Viso, Iñaki, La memoria de los hombres santos..., p. 459

79. En efecto, así como señala Pierre Chastang, «les actes de la partie liminaire (avant que ne débute le classement topographique) tracent des perspectives et ouvrent à la compréhension de l'ensemble du projet» (los documentos de la parte liminar (antes de que comience la clasificación topográfica) dibujan las perspectivas y permiten la comprensión del conjunto del proyecto). Chastang, Pierre, Lire, écrire, transcrire.., p. 65.

80. Como señala M. Durany, «formado por la cuenca del río Oza, con una extensión aproximada de unos 250 kilómetros cuadrados, el valle de Valdueza conforma una unidad espacial perfectamente definida por sus condiciones naturales (...) se trata de uno de los espacios más estrechamente vinculados al monasterio, tanto por las propiedades que forman parte de su dominio como por la autoridad que ejerce el abad sobre sus habitantes». DURANY, Mercedes, San Pedro durante la Edad Media..., p. 57.

81. TVSP, núms. 144 y 195.

82. En efecto, el pleito con los caballeros del Temple se debe a un malentendido originado por un privilegio de Alfonso IX de 1211 por el que devolvía a los templarios varias fortalezas y propiedades que les había arrebatado. Entre ellas destaca Ponferrada que fue devuelta con todos sus derechos y alfoces entre lo que se encontraba el valle de Valdueza, reclamado entonces por los templarios. Así se inició un pleito que fue zanjado por el propio rey en 1218 a favor de los monjes. TVSP, $n^{\circ} 283$. Sin embargo, años más tarde volvería a resurgir esta disputa debido a una manda testamentaria hecha por Andrés Iváñez a favor de los templarios que incluía varias posesiones en Villanueva, dentro del coto de Valdueza. En esta ocasión, fue el obispo de Astorga el encargado de dirimir el pleito en 1235. Se propuso un intercambio de propiedades: las de Villanueva pasaron a San Pedro y las que esta casa poseía en Ponferrada fueron entregadas a los templarios. Además, se acordó que el Temple no podía poseer nada en Valdueza con la excepción de que si otra orden lo conseguía ellos adquirirían también posesiones y derechos. TVSP, $n^{\circ} 293$. Por su parte, el pleito con el monasterio de Santiago de Peñalba tuvo lugar en 1251 con motivo de aclarar «sobre los montes e sobre los devisos: 
Estos conflictos se prolongaron a lo largo de la centuria señalada y, pese a que los monjes obtuvieron la confirmación de sus derechos en la mayoría de los casos, tanto el volumen documental generado como la importancia de las autoridades intervinientes en estos pleitos nos informa de las dificultades atravesadas por la comunidad monástica ante la pujanza de los poderes cercanos y el atractivo que el valle de Valdueza ejercía sobre los mismos ${ }^{83}$.

El segundo de los asuntos que recibe una atención preferente en estos folios del tumbo es el relativo a las propiedades del monasterio en Morales de Rey mediante tres diplomas regios, uno de los cuales contiene, en realidad, una sentencia emitida por los jueces de la martiniega en el pleito habido entre los monjes y los regidores de Benavente por el cobro de este impuesto ${ }^{84}$. La demanda de protección regia para las posesiones del cenobio sobre Morales de Rey junto con la atención dedicada a este enclave en la relación de propiedades contenidas en la segunda parte del cartulario nos informa no sólo de la importancia del mismo para el conjunto del dominio monástico sino también de los esfuerzos consagrados por los monjes a su defensa ante las documentadas y las presumibles presiones del entorno ${ }^{85}$. El tercero de los temas al que se dedican los primeros folios del tumbo mediante dos diplomas de donación regia alude a los derechos del cenobio sobre Pobladura de Valduerna en territorio de Palacios de Rey ${ }^{86}$. La presencia de estos documentos en una parte tan destacada del cartulario pudiera explicarse por los múltiples cambios de jurisdicción que afectaron a estos territorios y que perjudicaron el dominio monástico sobre los mismos. En efecto, entre la concesión de ambos privilegios parece que se produjo un breve periodo de posesión regia de las propiedades implicadas que fue solventado por Alfonso IX; sin embargo, desde I234 Palacios de Rey y su jurisdicción volvieron a ser patrimonio regio, situación que perduró hasta el siglo siguiente cuando fue convertido en señorío jurisdiccional de los Bazán ${ }^{87}$. Así, como apunta Iñaki Martín Viso ${ }^{88}$, el énfasis que revela esta parte inicial del cartulario acerca de la legitimación del dominio señorial sobre el

quales eran de Sant Pedro e quales de Santiago» lo cual supuso otra amenaza para el mantenimiento de la jurisdicción de los monjes sobre el coto de Valdueza. TVSP, $n^{\circ} 308$. Finalmente, respecto a los abusos cometidos por los agentes reales señalar que en 1257 Alfonso X suprime para siempre el merino en la tierra de Valdueza ante los daños y abusos cometidos por estos oficiales regios en el ejercicio de sus funciones. En 1277 este mismo monarca anuncia a sus oficiales la exención de pechos al monasterio. TVSP, núms. 338 y 371.

83. Síntoma de las dificultades de los monjes para controlar su dominio en el valle es el nombramiento por el abad de un encomendero para que asumiera el amparo y su defensa. TVSP, p. 632.

84. TVSP, núms. 199, 290 y 325.

85. Dentro de la colección documental contenida en el TVSP encontramos los siguientes documentos alusivos a este enclave: núms. 199, 220, 225, 240, 267, 290, 325, 339, 341, 354; 1, 3 (segunda parte. La enumeración contenida en este inventario alusivo a las rentas de pan comienza por el término de Morales de Rey), 54 y 55 (segunda parte. Este documento referido fue escrito con mucha posterioridad al corpus primigenio).

86. TVSP, núms. 203 y 246.

87. En el siglo XI el enclave posteriormente conocido como Palacios de Rey o Palacios de Valduerna fue elegido por Alfonso $\mathrm{V}$ como refugio ante las tropas musulmanas y como residencia veraniega. Desde este lugar, mencionado por Sampiro en su crónica, convocó armas y dirimió algunos pleitos. RuBıo PéREZ, Laureano Manuel, «La Valduerna: de la dominación romana al señorío jurisdiccional de los Bazán», Archivos Leoneses, vol. 21, nº 45 (1981), p. 19.

88. MarTín VIso, Iñaki, La memoria de los hombres santos..., p. 459. 
entorno del monasterio también pudiera justificarse por la proliferación de villa regias que habían surgido entre los siglos XII y XIII. El último de los asuntos que destaca en estos folios iniciales es la reiterada disputa por las propiedades foreras con los condes de San Román de la Hornija. Este enclave a orillas del Duero constituía el punto más alejado del monasterio y el único priorato que dependía de él, según consta en la mención del prior Guterus Petri en iı69. A este pleito se dedican cinco documentos, entre ellos dos sentencias, que evidencian la importancia de este conflicto que se prolongó durante más de diez años y que finalizó sin una victoria clara para la comunidad monástica ${ }^{89}$.

En resumen, el análisis del contenido de los documentos iniciales del TSPM nos informa del imperativo de salvaguarda de los derechos y privilegios monásticos que justifica la confección de este proyecto. Este propósito se refuerza con la inserción en los folios finales de esa sección inaugural de las bulas papales que confirman las propiedades monásticas ${ }^{90}$. Si bien, como ha sido señalado, la memoria del periodo fundacional del cenobio y, consecuentemente la recuperación de los hombres santos sobre cuyas acciones se sustentó el prestigio del monasterio como centro receptor de donaciones y voluntades, al menos durante sus primeros siglos de existencia, no recibió ninguna atención en la sección liminal del TSPM, con excepción del falso de Ordoño II. Consecuentemente, la exaltación del pasado próximo del monasterio se erige como el nuevo referente que articula la memoria de San Pedro de Montes, incluso por encima de sus santos fundadores y de otras prestigiosas figuras, como el obispo Ranulfo, sobre cuyas acciones, reales o supuestas, se había construido el discurso monástico años antes.

89. En 1124 la reina Urraca concede al abad Pelayo el priorato de San Román de Hornija, cerca de Toro. La reina establece el coto del territorio y las cláusulas propias del traslado jurisdiccional. La presencia en el priorato del cargo de bodeguero revela la importancia de este enclave vitivinícola para el monasterio. En 1261, los condes de San Román de la Hornija, doña Elvira Fernández y sus hijos Rodrigo y Alvar Rodríguez, entablan pleito con el monasterio de Montes sobre los hombres de este territorio que pasaban con heredades foreras del abandego al condado. Los condes apelan que esta era la práctica habitual desde hacía más de cuarenta años pero los monjes alegan que San Román pertenecía al señorío monástico desde su donación por la reina Urraca y la confirmación de sus derechos al monasterio por Alfonso IX. La sentencia regia emitida en junio de 1261 favoreció las peticiones del cenobio. Pese a este dictamen, el enfrentamiento con los condes volvió a reavivarse en 1271. En esta ocasión, fue el maestre Fernando el encargado de resolver la disputa en enero de 1272 estableciendo una avenencia entre ambas partes. TVSP, núms. 350 y 363.

90. TVSP, $\mathrm{n}^{\circ} 267$, Bula de 1202 del papa Inocencio II por la que confirma las propiedades del monasterio; $\mathrm{n}^{\circ} 303$, Bula de 1286 de Honorio IV confirmando las posesiones del monasterio; $n^{\circ} 303$, Breve del papa Inocencio IV con fecha de 1249. Este último documento es más bien una resolución graciosa por la que se concede exención en la provisión de beneficios y pensiones eclesiásticas. Según Augusto Quintana, el motivo de esta concesión se debe al pleito que el abad mantenía con los monjes por la provisión de cargo eclesiástico en la capilla Domiz. Sobre este asunto volveré más adelante. TVSP, pp. 65-66. Según Paul Bertrand, el crecimiento de la demanda de las bulas papales como instrumento de legitimación de las pretensiones monásticas en el siglo XIII se debe a su transformación progresiva en elementos de protección casi sagrados y a su carácter eterno, a diferencia de lo ocurrido con los diplomas de confirmación y concesión regíos. BERTRAND, Paul: Les écritures ordinaires. Sociologie d'un temps de révolution documentaire (1250-1350). Paris, Publications de la Sorbonne, 2015, p. 31. 


\section{LA RESTITUCIÓN DE LA MEMORIA EN LAS INCORPORACIONES DEL TUMBO DE SAN PEDRO DE MONTES}

Al margen de las intenciones de redacción del corpus primigenio de este cartulario, es evidente que las incorporaciones a las que fue sometido posteriormente sirvieron para actualizar o, incluso, alterar su discurso inicial y, consecuentemente, la memoria contenida en sus folios. Así, como ha sido señalado, el trabajo sobre el corpus primigenio se caracterizó por una selección de la nómina de diplomas manipulados en el cenobio durante el periodo de la reforma que implicó la exclusión de tres diplomas referentes a las acciones del obispo Ranulfo sobre el monasterio. Su conservación se debe a una mano posterior que, en la primera mitad del siglo XIV y aprovechando unos folios en blanco del decimotercer cuaderno dispuesto entre la primera y segunda parte del tumbo, copió en letra gótica fracturada y seguidamente estos tres diplomas ${ }^{91}$. Parece que con esta operación el segundo copista trataba de suplir lo que a su juicio constituía una notable carencia del cartulario. No obstante, con esta incorporación documental se alteraba parcialmente el discurso propuesto en el corpus primigenio dado que ciertas informaciones contenidas en estos diplomas espurios contradecían o modificaban las ofrecidas por otros documentos ya transcritos. En efecto, así, por ejemplo, según la versión incluida posteriormente la concesión del coto monástico recaía exclusivamente sobre el obispo Ranulfo en lugar de sobre el monarca Ordoño II, al igual que la donación de la iglesia de Redelga.

La alteración que supuso esta nueva versión de los hechos se percibe limitada, en cuanto al uso o lectura conjunta de este códice, debido a la disposición alejada de estos documentos entre sí. No obstante, el éxito de esta operación de inclusión documental fue máximo debido a que han sido precisamente estos diplomas copiados posteriormente los que han condicionado buena parte del criterio de los historiadores sobre la reconstrucción de la historia de este cenobio. En efecto, escasa repercusión ha tenido entre los interesados por este monasterio la inicial exclusión de estos documentos respecto al corpus primigenio del TSPM. Así, este ejercicio de selección memorial, que nos informa no sólo de la cuestionada utilidad de estos diplomas para los propósitos de confección primigenia de este cartulario sino también sobre las posibles reticencias existentes en torno a su tradición documental o a la validez de su contenido, ha pasado desapercibido

91. Existe un error en la foliación asignada por Augusto Quintana a estos diplomas siendo el orden correcto el siguiente: TVSP, $n^{\circ}$ 2, f. 106 r-v; n ${ }^{\circ}$, f. 106 v; $n^{\circ}$ 4, f. 105 r-106r. Es necesario señalar que justo inmediatamente antes de estos documentos este mismo copista incorpora otros tres diplomas del rey Sancho IV en el siguiente orden: TVSP, núms. 378,379 y 384, ff. 104v-105r. Se trata por tanto de un considerable ejercicio de recuperación de la memoria monástica la que realiza este copista en atención, sobre todo, a la relevancia de los personajes implicados en estos negocios. Asimismo, esta serie documental constituye una de las pocas atribuciones a una sola mano que se pueden identificar en este cartulario, al margen de su corpus primitivo. 
para los investigadores lo que supone una limitación en el uso de la información expuesta en el TSPM.

Con todo, otras incorporaciones realizadas sobre este códice diplomático también significaron un notable ejercicio de creación memorial. El ejemplo más sobresaliente se refiere a la copia del diploma de confirmación del coto monástico por Sancho IV en el primer folio del cartulario. Según Augusto Quintana, la inclusión de este documento se produjo en fecha muy posterior a la primitiva confección del tumbo, aunque, en realidad, el estudio de su letra establece que debió de copiarse a finales del siglo XIII o en los primeros años del XIV. Esto es, en una fecha bastante próxima a su concesión. La copia de este diploma no perturbaba en absoluto el discurso proyectado en los folios iniciales del tumbo, a diferencia de otros casos de alteración documental en cartularios monásticos como, por ejemplo, en el Becerro de San Pedro de Arlanza cuya modificación en su folio inaugural implicó una decisiva transformación en la jerarquía de benefactores del cenobio ${ }^{92}$. En el caso de San Pedro de Montes esta alteración servía para reforzar la imagen de protección regia al cenobio proyectada en el cartulario, legitimando el contenido del falso de Ordoño II, al tiempo que otorgaba un protagonismo destacado a la intervención del rey Sancho IV sobre el cenobio. Ciertamente, el recuerdo de la actuación de este monarca recayó exclusivamente en las incorporaciones que de forma dispersa tanto en el tiempo como en la propia arquitectura del tumbo completaron la colección documental transcrita en sus folios.

Existen otros casos de actualización de la memoria contenida en el cartulario como testimonio de las ausencias detectadas por sus usuarios respecto al corpus primitivo. Un ejemplo que destaca por el volumen documental implicado y por las repercusiones de su inclusión en la estructura del tumbo es el que se refiere al pleito por el derecho de patronato sobre la capilla Domiz, dependiente de la iglesia de San Martín de Alijo en Valdeorras. A este conflicto que enfrentó a la comunidad monástica con el clérigo y los feligreses de Domiz entre los años I250 y 253 se dedicaron doce documentos, aunque diez de ellos recibieron una única numeración en el tumbo ${ }^{93}$. Todos estos diplomas fueron copiados por una misma mano entre los folios 94 y 97 del cartulario a modo de micro dossier constituido con la intención de otorgar información pertinente sobre este pleito que había sido obviado inicialmente. Es necesario señalar que la inclusión de esta serie documental se hizo seguidamente al diploma que cerraba, originariamente, la

92. AzCÁRATE, Pilar et alii, «Volver a nacer: historia e identidad en los monasterios de Arlanza, San Millán y Silos (siglos XII-XIII), en Cahiers d'études hispaniques medievales, n² 29, 2006, pp. 372-373.

93. La iglesia de San Martín de Alijo en Valdeorras, de propiedad particular en sus orígenes, pasó a depender del monasterio de san Pedro de Montes en el año 1083 por donación de don Diego. TVSP, $n^{\circ} 37$. Posteriormente, los pobladores de este núcleo edificaron una capilla llamada de Domiz, dependiente de la iglesia señalada, que fue inicialmente provista por el abad de san Pedro. Sin embargo, en la primera mitad del siglo XIII vacó esa capilla y un arcediano de la catedral astorgana fue el encargado de nombrar a propuesta de los feligreses a un nuevo clérigo. Se inició entonces un largo pleito que, tras varias amenazas de excomunión y sentencias, se resolvió a favor de los monjes en 1252. TVSP, núms 22 a 33 (segunda parte). 
primera parte del corpus primigenio en el folio 94 recto y aprovechando los otros dos folios restantes que quedaban en blanco de este cuaderno. Con todo, fue necesario incorporar un nuevo cuaderno para recoger los últimos documentos concernientes a este pleito lo que supuso una modificación importante en la originaria estructura de este códice diplomático. Además, la relevancia concedida a este bloque documental se percibe en la inclusión de una nueva entrada alusiva en el índice primitivo. Referente a las motivaciones que indujeron a esta operación de copia puede que el resurgimiento de ciertos problemas respecto a los derechos monásticos sobre esta propiedad motivase a un copista anónimo a incorporar el recuerdo de esta disputa jurisdiccional.

En definitiva, este breve repaso por algunas de las incorporaciones más destacadas de las que fue objeto en el TSPM constituye un ilustrativo ejemplo de cómo estas modificaciones sobre el trabajo primigenio de confección de este cartulario no sólo sirvieron para aumentar su valor como corpus transmisor de documentos sino que también contribuyeron a su función de (re)creador de la memoria institucional del cenobio mediante la actualización, la ampliación o, incluso, la modificación de su discurso inicial.

\section{CONCLUSIONES}

El valor del Tumbo de San Pedro de Montes como único testimonio documental de la memoria de este famoso monasterio berciano le ha otorgado un merecido protagonismo entre los investigadores interesados por reconstruir su historia, entre otros aspectos. Con todo, la memoria contenida en sus folios responde a un proyecto intencionado de selección y clasificación de la información disponible con la finalidad de confeccionar un discurso que sirviese no sólo para articular ordenadamente la justificación y administración del patrimonio de los monjes sino también para construir y defender su identidad como grupo privilegiado dentro del sistema social. Sin embargo, el empleo de este cartulario monástico por parte de los especialistas evidencia, por lo general, una falta de atención a las lógicas de producción que determinaron la elección y disposición de su contenido. Esto es a las diferentes estrategias que condicionaron su significado como proyecto historiográfico y que permiten la identificación de los diferentes parámetros memoriales que sirvieron para la elaboración mutable de su discurso.

En efecto, la recuperación del pasado lejano de la institución en los folios de este códice diplomático no sólo nos permite conservar la memoria de este tiempo mitificado sino que también nos facilita la identificación de los años finales del siglo XI y primeros del XII como un momento de forzosa recreación de la historia monástica debido a las presiones reformistas. La polémica actuación del obispo Ranulfo sobre el cenobio junto con la remembranza de los hombres santos vinculados al mismo en su etapa fundacional constituyen los referentes memoriales 
que pretendían avalar el patronazgo episcopal sobre el monasterio como defensa de su independencia frente a la intervención del poder regio. Sin embargo, la particular selección a la que fueron sometidos los documentos sospechosos resultantes de esta etapa de reformulación de la historia monástica en el tumbo evidencia la falta de utilidad de este periodo fundacional para los propósitos demandados en su confección. Contrariamente, a finales del siglo XIII cuando se elabora este proyecto escriturario es la exaltación del patronazgo regio y papal el nuevo parámetro memorial que articula la apertura del discurso monástico. La sección liminal del cartulario hace alarde principalmente de esta nueva forma de intervención real como recurso ante las dificultades atravesadas por los monjes frente a las crecientes presiones del entorno. Esto es, el pasado próximo es el nuevo referente temporal que gestiona la estrategia discursiva manifiesta en la primigenia redacción de este códice. Con todo, la posibilidad de incorporación de nuevos documentos por parte de los usuarios de este cartulario representa un tercer momento de creación memorial en su confección. Ciertamente, se trata de una etapa fuertemente diversa ya sea por el contenido de los textos incorporados, por su copista o por su fecha de inclusión y localización en el tumbo. Una diversidad que también se evidencia en la falta de estrategia uniforme respecto al momento de referencia temporal de estas incorporaciones. No obstante, estas adiciones sirvieron para incrementar el valor del códice como corpus transmisor de documentos al tiempo que reforzaron su función como promotor de la memoria institucional del monasterio, al margen de las posibles alteraciones que supusieron respecto a su discurso inicial.

En conclusión, pese a que las etapas de referencia temporal de los parámetros memoriales analizados han sido reconocidas por los investigadores esta operación no ha implicado necesariamente la correspondiente identificación de los momentos de creación memorial a los que pertenecen. Esto se debe a un déficit en el análisis de cómo las lógicas de producción del tumbo contribuyeron a la creación del discurso propuesto en sus folios y de cómo las operaciones de selección, clasificación e incorporación documental en él realizadas entraron en contradicción, revalidación o, incluso, desuso con el discurso propuesto. Consecuentemente, el análisis del tumbo de San Pedro de Montes se demuestra útil no sólo para valorar la compleja materialidad de este cartulario como fuente histórica sino también para entender la maleabilidad a la que fue sometida la memoria institucional del cenobio en virtud de las diferentes estrategias discursivas que determinaron su producción. 


\section{BIBLIOGRAFÍA}

AgúNDEZ SAN Miguel, Leticia, «Estudio de las transformaciones formales y funcionales en el género de los cartularios: el ejemplo de los becerros del monasterio de Sahagún (siglos XI-XIV)», Journal of Medieval Iberian Studies, 7:I, 2015, pp. 44-56.

Alonso Álvarez, Pedro, Historia del monasterio de San Pedro de Montes (646-2003), Arganza, Ed. Pedro Álvarez, 2006.

Álvarez Palenzuela (coord.), Actas de San Pedro de Montes. Luz en la memoria, Ponferrada, Instituto de Estudios Bercianos, 2006.

Álvarez Villar, Julián, «Breve Historia de San Pedro de Montes», Estudios Bercianos, 26 (200I), pp. I05-III.

Azcárate, Pilar, Escalona, Julio, Jular, Cristina y Larrañaga, Miguel, «Volver a nacer: historia e identidad en los monasterios de Arlanza, San Millán y Silos (siglos XII-XIII), en Cahiers d'études hispaniques medievales, $\mathrm{n}^{\circ} 29$, 2006, pp. 359-394.

Bertrand, Paul: Les écritures ordinaires. Sociologie d'un temps de révolution documentaire (I250-I350). Paris, Publications de la Sorbonne, 2015.

Bouchard, Constance, «Monastic cartularies: organizing eternity», en Kosto, Adam y Winroth, Anders (eds.): Charters, cartularies and archives: the preservation and transmission of documents in the medieval west. Toronto, Pontifical Institute of Mediaeval Studies, 2002, pp. 22-32.

Bouchard, Constance, Rewriting saints and ancestors. Memory and Forgetting in France, 500-I200, Philadelphia, Penn, 20I5, pp. 9-37.

Calleja Puerta, Miguel, «Cartularios y construcción de la memoria monástica en los reinos de León y Castilla durante el siglo XII», en LAMAZOU-Duplan, Veronique y RAMIREZ VAQUERO, Eloísa (dirs.): Les cartulaires médiévaux. Écrire et conserver la mémoire du pouvoir, le pouvoir de la mémoire, Pau, Puppa, 2013, pp. I87-I97.

Chastang, Pierre, Lire, écrire, transcrire: Le travail des rédacteurs de cartulaires en BasLanguedoc (XIe-XIIle siècles), Paris, CTHS, 2002.

- «Culture médiévale de l'écrit et cartulaires», en Munita Loinaz, José Antonio (coord.): Mitificadores del pasado, falsarios de la Historia. Historia, Bilbao, Universidad País Vasco, 2012, pp. 67-87.

- «Écrire, remployer, archiver. Quelques remarques sur 1'évolution de la culture de 1'écrit au Moyen Âge central», en VV. AA.: La cultura en la Europa del siglo XIII. Emisión, intermediación, audiencia, Pamplona, Gobierno de Navarra, 2014, pp. 135-156.

Domínguez, Celestino, Cartulario latino de San Pedro de Montes: transcripción del texto, comentario morfosintático, léxico. Tesis doctoral, León, Universidad de León, I99I.

DuRANy, Mercedes y RodríGuez GonZÁLEz, María del Carmen, «El señorío de un monasterio berciano. San Pedro de Montes en el valle de Valdueza (900-I300)», en VV. AA.: Semana de Historia del monaquismo Cántabro-Astur-Leonés, Oviedo, I982, pp. 335-359.

- «El sistema antroponímico en El Bierzo: tumbo de San Pedro de Montes. Siglos IX al XIII», en Martínez Sopena, Pascual (coord.): Antroponimia y sociedad, Santiago de Compostela, I995, pp. 73-I02. 
Durany, Mercedes, San Pedro de Montes. El dominio de un monasterio benedictino de El Bierzo (siglos XI-XIII), Institución Fray Bernardino, León, I976.

- La región del Bierzo en los siglos centrales de la Edad Media, IO70-I250, Santiago de Compostela, Universidad de Santiago de Compostela, I989.

- «San Pedro de Montes en la Edad Media», en Álvarez Palenzuela (coord.): Actas de San Pedro de Montes. Luz en la memoria, Ponferrada, Instituto de Estudios Bercianos, 2006, pp. 27-77.

Escalona, Julio y Sirantoine, Hélene (dirs.) : Chartes et cartulaires comme instruments de pouvoir. Espagne et Occident chrétien (VIII ${ }^{e}-X I I^{e}$ siècles), Tolouse, 2014.

FLórez, Henrique, España Sagrada, Tomo XV, Madrid, I759.

García Andreva, Fernando, El Becerro Galicano de San Millán de la Cogolla. Edición y estudio, Logroño, Cilengua, 2010.

GARCíA DE CORTÁZAR, José Ángel, «La construcción de la memoria histórica en el monasterio de San Millán de la Cogolla (IO9O-I240», en Cordero Rivera, Juan (coord.): Los monasterios riojanos en la Edad Media: historia, cultura y arte, Logroño, Ateneo riojano, 2005, pp. 7I-94.

- «Los monasterios del reino de León y Castilla a mediados del siglo XI: un ejemplo de selección de las especies», en García de Cortázar, José Ángel (coord.): Monjes y monasterios hispanos en la Alta Edad Media, Aguilar de Campoo, Fundación Santa María la Real, 2006, pp. 255-288.

Geary, Patrick, «Entre gestion et gesta», en Guyotjeannin, Olivier, Morelle, Laurent y PARISSE, Michel (coords.): Les Cartulaires. Actes de la Table ronde organisée par l'Ecole nationale de chartes et le G.D.R. I2I du C.N.R.S. (Paris, 5-7 décembre I99I). Paris, École de Chartes, I993, pp. I3-25.

Gómez Moreno, Manuel, Catálogo monumental de España. Provincia de León. León, Instituto Leonés de cultura, I908.

GonzÁlez Rodríguez, Rafael, «Los relieves altomedievales de la ermita de la Santa Cruz de Montes de Valdueza», Estudios Bercianos, 32-33 (2008), pp. 53-78.

Herrezuelo, Joaquín, Historia de San Pedro de Montes, Archivo Diocesano de Astorga.

Kosto, Adam, «The Liber feudorum maior of the counts of Barcelona: the cartulary as an expression of power», Journal of Medieval History, vol. 27/I (200I), pp. I-22.

Linage Conde, Antonio, Los orígenes del monacato benedictino en la Península Ibérica, Tomo II, León, Centro de Estudio e Investigación San Isidoro, I973.

Luengo, José María, «De la Tebaida leonesa: Montes y Penalba», Revista Tierras de León, 22 (ig62), pp. 25-4I.

Martín Viso, Iñaki, «Monasterios y redes sociales en el Bierzo altomedieval», Hispania, 237 (20II), pp. 9-38.

— «La memoria de los «hombres santos» en el monacato hispano: el caso de la región del Bierzo», Imago temporis. Medieum Aevum, no 6 (2012), pp. 440-46I.

Martínez Díez, Gonzalo, Colección documental del monasterio de San Pedro de Cardeña, Caja de ahorros del círculo católico de obreros de Burgos, Burgos, I998.

Martínez Fuertes, Benjamín, Montes y Peñalba: ensayo histórico-artístico, La Carruna, ed. A. Álvarez, 2004.

Martínez Tejera, Artemio Manuel, «San Pedro de Montes y la ermita de la Santa Cruz», Historia I6, 227 (1995), pp. II2-II7.

- «Cenobios leoneses altomedievales ante la europeización: San Pedro y San Pablo de Montes, Santiago y San Martín de Peñalba y San Miguel de Escalada», Hispania Sacra, I09 (2002), pp.87-I08. 
Pensado Torné, José Luis, «El léxico Hispánico Occidental en el «Tumbo Viejo» de San Pedro de Montes», Anuario galego de filoloxia, Io (1983), pp. 43-78.

PeÑa Pérez, Francisco Javier, «La creación de memoria histórica: San Pedro de Cardeña», en GARcía de CorTÁZAR, José Ángel (coord.): Los grandes monasterios benedictinos de época románica (I050-I200), Aguilar de Campoo, Santa María La Real, 2007, pp. 217-24I.

Pérez González, Maurilio, «Galleguismo y/o leonesismos en el Tumbo de San Pedro de Montes», Contextos, 25-26 (I995), pp. I35-150.

Peterson, David, «Reescribiendo el pasado. El «Becerro Galicano» como reconstrucción de la historia institucional de San Millán de la Cogolla», Hispania, 69 (2009), pp. 653-682.

Puente, Ricardo, Los monasterios de Santiago de Peñalba y de San Pedro de Montes, León, Ed. R. Puente, I992.

Quintana Prieto, Augusto, Tumbo Viejo de San Pedro de Montes, León, Centro de Estudios e Investigación san Isidoro, I97I.

Quintana, Augusto, «El privilegio de Ordoño Il a San Pedro de Montes», Archivos Leoneses, 2I (I957), pp. 77-I34.

Remensnyder, Amy, Remembering Kings Past. Monastic foundation Legends in Medieval Southern France, Cornell University Press, Ithaca, I996.

Rodríguez, Elena E. y CARCíA, Antonio C. (coords.): La escritura de la memoria: los cartularios, Huelva, Universidad de Huelva, 2oII.

Rodríguez GonzÁlez, María del Carmen, Estructura económica del dominio del monasterio de San Pedro de Montes hacia I300. Tesis de Licenciatura, Universidad de Santiago de Compostela, I975.

Rubio Pérez, Laureano Manuel, «La Valduerna: de la dominación romana al señorío jurisdiccional de los Bazán», Archivos Leoneses, vol. 2I, nº 45 (I98I), pp. 15-34.

SANZ Fuentes, María Josefa, «Cartularios: historia y falsificación histórica», en GARCía DE CorTÁZAR, José Ángel (coord.): La memoria histórica de Cantabria, Santander, Universidad de Cantabria, I996, pp. I47-I54.

Sот, Michel, «Autorité du passé lointain, autorité du passé proche dans 1' historiographie épiscopale (VIII ${ }^{\mathrm{e}}-\mathrm{XI}^{\mathrm{e}}$ siècle). Les cas de Metz, Auxerre et Reims», en SANSTERre, JeanMarie (coord.) : L'autorité du passé dans les sociétés médiévales. Rome, École française de Rome, 2004, pp. I39-I75.

Testón Turiel, Juan Antonio, El monacato en la diócesis de Astorga en los periodos antiguo y medieval: la tebaida berciana, León, Universidad de León, 2008, pp. 315-330.

TINTI, Francesca, «Si litterali memorie commendaretur: memory and cartularies in eleventhcentury Worcester», en Baxter, Simon (ed.), Early Medieval Studies in Memory of Patrick Wormald, Farnham, Asghate, 2009.

— «Fuentes escritas: transcripción, digitilización, historia social de la cultura escrita», en López OJEDA, Esther (coord.): Nuevos temas, nuevas perspectivas en historia medieval, Logroño, Instituto de Estudios Riojanos, 2015, pp. 59-82.

TомÁs FACI, Guillermo, «La construcción de la memoria escrita en los archivos eclesiásticos de Ribagorza (ss. XI-XIII)», Edad Media. Revista de Historia, I6 (2015), pp. 89-I05.

VANDERPUTten, Steven, Reform, Conflict, and the Shaping of Corporate Identities, Collected studies on Benedictine Monasticism I050-II5O, Munster, Lit Verlang, 2013.

Zaragoza i Pascual, Ernesto, «Abadologio de san Pedro de Montes (siglos VII-XIX)», Compostellanum, 57 (2012), pp. 277-312. 
Calidad de Revistas

científicas Españolas

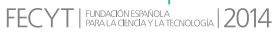

SERIE III HISTORIA MEDIEVAL

REVISTA DE LA FACULTAD DE GEOGRAFİA E HISTORIA
AÑO 2016

ISSN: 0214-9745

E-ISSN 2340-1362

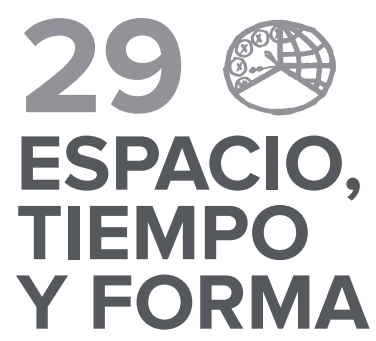

\section{Artículos}

17 Leticia Agúndez San Miguel

El tumbo de San Pedro de Montes como instrumento de recreación de la memoria instituciona

\section{Roberto Antuña Castro}

La copia de escrituras públicas a la muerte del notario titular

75 Carlos de Ayala Martínez

Alfonso VIII, Cruzada y Cristiandad

\section{Carlos Barquero Goñ I}

La renta señorial de la Orden de San Juan en Castilla durante los siglos XII y XIII

\section{MARgARITA CABRERA SÁNCHEZ}

Cristianos nuevos y cargos concejiles. Jurados conversos en Córdoba a fines del Medievo

183 Francisco de Paula Cañas Gálvez

La correspondencia de Leonor de Alburquerque con su hijo Alfonso $V$ de Aragón: acción política y confidencia familiar del partido aragonés en la corte de Castilla (1417-1419)

\subsection{Octavio Colombo} del siglo XV

Los dueños del dinero. Prestamistas abulenses a mediados

\section{Alfonso Domínguez de LA CONCHA \\ Apropiaciones de comunales en la Puebla de Guadalupe} (Cáceres) durante la Baja Edad Media

\section{Antonio Vicente Frey SÁnChez}

Sobre la articulación administrativa de la cuenca del río Segura entre los siglos VII y VIII: algunos recientes elementos para identificar una frontera «blanda»

\section{DaVid Gallego VALLE}

La fortificación medieval en el Campo de Montiel (ss. VIII-XVI). Análisis de su secuencia histórica y constructiva

\section{MAURICIO HERRERO JIMÉNEZ}

El cuidado del alma y otros cuidados en las cartas de aniversario del cabildo de los clérigos de Cuéllar en el siglo XIV
4.01 JaIME DE HOZ OnRuBIA

Antroponimia y reconstrucción histórica: consideraciones sobre la identificación personal en el paso de la Edad Media a la Moderna en la Corona de Castilla

\section{Carmen López Martínez \\ Sancho IV de Castilla y la imposición del diezmo mudéjar} en Murcia

\subsection{PABlo Martín Prieto} el valor de los preámbulos

Idea e imagen del rey en la diplomática medieval hispana:

\section{Luis Martínez García}

Los campesinos al servicio del señor, según los fueros locales burgaleses de los siglos XI-XIII

543 Juan José Morales Gómez

Las minas de alumbre del bajo jiloca (Zaragoza) y su explotación a fines de la Edad Media

571 DAVID D. NAVARRO

Precisiones literarias sobre el antijudaísmo de Gonzalo de Berceo en el Milagro de Teófilo (XXIV)

593 JaIME PIQUeras JuAN

Matrimonios en régimen de germania y relaciones intrafamiliares en Alicante durante el siglo XV

621 Aída Portilla GonzÁlez

El arte del buen morir en los testamentos medievales de la catedral de Sigüenza (siglos XIII-XV)

675 María Del Pilar Rábade Obradó

Justas, fiestas y protagonismos: Alegrías y placeres en El Victorial de Gutierre Díaz de Games

699 TERESA SÁnchez ColladA

La dote matrimonial en el Derecho castellano de la Baja Edad Media. Los protocolos notariales del Archivo Histórico Provincial de Cuenca (1504-1507)

\section{Casto Manuel Solera Campos}

Pureza y continencia durante la Edad Media: la castidad conyugal en la Orden de Santiago (siglos XII-XVI)

\section{7 ÓsCAR VILLARROEL GONZÁlEZ}

Autoridad, legitimidad y honor en la diplomacia: los conflictos anglo-castellanos en los concilios del siglo XV

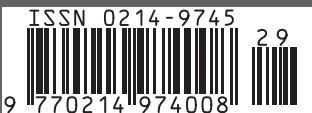




\section{9}

\section{ESPACIO,}

\section{TIEMPO}

Y FORMA

UกED

SERIE III HISTORIA MEDIEVAL

REVISTA DE LA FACULTAD DE GEOGRAFİA E HISTORIA

\section{Libros}

817 Álvarez Fernández, María y Beltrán SuÁrez, Soledad, Vivienda, gestión y mercado inmobiliarios en Oviedo en el tránsito de la Edad Media a la modernidad. El patrimonio urbano del cabildo catedralicio (RobERTO J. GONZÁlez ZALACAín)

821 BeCEIro PITA, Isabel (dir.), Poder, piedad y devoción. Castilla y su entorno, siglos XII-XV (ANA ECheVARría ARSUAGA)

825 García Fernández, Ernesto (Coord.), Laguardia y sus fueros. Estudios Históricos realizados en conmemoración del 850 aniversario de la concesión de la carta fundacional (ANA MARÍA RIVERA MEDINA)

829 García Fernández, Ernesto y Bonachía Hernando, Juan Antonio (eds.), Hacienda, mercado y poder al Norte de la Corona de Castilla en el tránsito del Medievo a la Modernidad (AnA María Rivera Medina)

843 Martín Prieto, Pablo, Las matemáticas en la Edad Media: una historia de las matemáticas en la Edad Media occidental (ANTONIO HERNANDO Esteban)

847 Miranda García, Fermín, Breve Historia de los Godos (Ana María JIMÉNEZ GARNICA)

851 Moreno Ollero, Antonio, Los dominios señoriales de la Casa de Velasco en la Baja Edad Media (DIEGo ARSUAGA LABORDE)

855 ORTEgo Rico, Pablo, Poder financiero y gestión tributaria en Castilla: Los agentes fiscales en Toledo y su reino (1429-1504) (Ana María Rivera Medina)

861 Solórzano Telechea, Jesús A. \& Arízaga bolumburu, Beatriz \& AgUiAR ANDRADE, Amélia (editores), Ser mujer en la ciudad medieval eUrOPEa (MARIANA ZAPATERO)

869 Solórzano Telechea, Jesús A. \& Arízaga bolumburu, Beatriz \& Sicking, Louis (eds.), Diplomacia y comercio en la Europa Atlántica Medieval (Roberto J. GonzÁlez Zalacaín)

875 VÍtORES CASADO, Imanol \& GoICOLEA JULIÁN, Francisco Javier \& ANGULO Morales, Alberto \& Aragón RuAno, Álvaro (edición y estudios), Hacienda, fiscalidad y agentes económicos en la Cornisa Cantábrica y su entorno (1450-1550). Nuevos textos para su estudio (ENRIQUE CANTERA MONTENEGRO) 